\title{
Functional Characterization of Alternative and Classical Pathway C3/C5 Convertase Activity and Inhibition Using Purified Models
}

\author{
Seline A. Zwarthoff', Evelien T. M. Berends' ${ }^{1}$, Sanne Mol', Maartje Ruyken ${ }^{1}$, Piet C. Aerts ${ }^{1}$, \\ Mihály Józsi ${ }^{2}$, Carla J. C. de Haas ${ }^{1}$, Suzan H. M. Rooijakkers ${ }^{1 *+}$ and Ronald D. Gorham Jr. ${ }^{1 \dagger}$ \\ ${ }^{1}$ Department of Medical Microbiology, University Medical Center Utrecht, Utrecht University, Utrecht, Netherlands, \\ ${ }^{2}$ Department of Immunology, ELTE Eötvös Loránd University, Budapest, Hungary
}

\section{OPEN ACCESS}

Edited by:

Tom E. Mollnes,

University of Oslo, Norway

Reviewed by:

Marcin Okrój,

Intercollegiate Faculty of

Biotechnology of University of

Gdańsk and Medical University

of Gdańsk, Poland

Elena Volokhina,

Radboud University Nijmegen

Medical Centre, Netherlands

*Correspondence:

Suzan H. M. Rooijakkers s.h.m.rooijakkers@umcutrecht.nl

tThese authors have contributed equally to this work.

Specialty section: This article was submitted to

Molecular Innate Immunity, a section of the journal

Frontiers in Immunology

Received: 23 May 2018 Accepted: 10 July 2018

Published: 23 July 2018

Citation:

Zwarthoff SA, Berends ETM, Mol S,

Ruyken M, Aerts PC, Józsi M, de Haas CJC, Rooijakkers SHM and

Gorham RD Jr. (2018) Functional

Characterization of Alternative

and Classical Pathway C3/C5

Convertase Activity and Inhibition

Using Purified Models.

Front. Immunol. 9:1691. doi: 10.3389/fimmu.2018.01691
Complement is essential for the protection against infections; however, dysregulation of complement activation can cause onset and progression of numerous inflammatory diseases. Convertase enzymes play a central role in complement activation and produce the key mediators of complement: C3 convertases cleave C3 to generate chemoattractant C3a and label target cells with C3b, which promotes phagocytosis; C5 convertases cleave C5 into chemoattractant C5a, and C5b, which drives formation of the membrane attack complex. Since convertases mediate nearly all complement effector functions, they are ideal targets for therapeutic complement inhibition. A unique feature of convertases is their covalent attachment to target cells, which effectively confines complement activation to the cell surface. However, surface localization precludes detailed analysis of convertase activation and inhibition. In our previous work, we developed a model system to form purified alternative pathway (AP) C5 convertases on C3b-coated beads and quantify C5 conversion via functional analysis of released C5a. Here, we developed a C3aR cell reporter system that enables functional discrimination between C3 and C5 convertases. By regulating the C3b density on the bead surface, we observe that high C3b densities are important for conversion of C5, but not C3, by AP convertases. Screening of well-characterized complement-binding molecules revealed that differential inhibition of AP C3 convertases (C3bBb) and C5 convertases [C3bBb(C3b)] is possible. Although both convertases contain C3b, the C3b-binding molecules Efb-C/Ecb and FHR5 specifically inhibit C5 conversion. Furthermore, using a new classical pathway convertase model, we show that these C3b-binding proteins not only block AP C3/C5 convertases but also inhibit formation of a functional classical pathway C5 convertase under well-defined conditions. Our models enable functional characterization of purified convertase enzymes and provide a platform for the identification and development of specific convertase inhibitors for treatment of complement-mediated disorders.

Keywords: innate immunity, inflammatory disease, convertase enzymes, complement, complement therapeutics, multi-molecular proteases

\section{INTRODUCTION}

The human complement system comprises a family of proteins that are essential to the human immune response against infections (1). Complement recognizes microbes or damaged host cells and subsequently triggers an enzymatic cascade that mainly serves to (a) label target cells for phagocytosis by immune cells, (b) produce chemoattractants, and (c) directly kill target cells via 
pore formation (2). Unwanted complement activation on the body's own cells is a key pathological driver in a wide spectrum of immune diseases including autoimmune, inflammatory, and degenerative diseases (3-5). For current and future development of therapeutic complement inhibitors, knowledge of complement activation and how it can be regulated is of great importance.

Convertase enzymes fulfill a central role in the complement cascade as they cleave $\mathrm{C} 3$ and $\mathrm{C} 5$, which mediate nearly all complement effector functions. C3 convertases cleave C3 into C3a, a chemoattractant molecule, and $\mathrm{C} 3 \mathrm{~b}$, which covalently binds to target surfaces and triggers phagocytosis. C5 convertases cleave C5 into C5a, a potent mediator of leukocyte recruitment and inflammation, and $\mathrm{C} 5 \mathrm{~b}$, the initiator of the membrane attack complex and cell lysis. The complement cascade begins via specific recognition of target cells in the classical (CP) and lectin (LP) pathways. In the CP, antibodies bind epitopes on the target

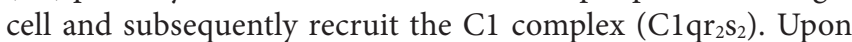
binding to the antibody platforms (6), C1q-associated protease $\mathrm{C} 1$ s converts $\mathrm{C} 4$ and $\mathrm{C} 2$ to generate a $\mathrm{C} 3$ convertase enzyme (C4b2a) on the cell surface (Figure 1A). Similarly, the lectin

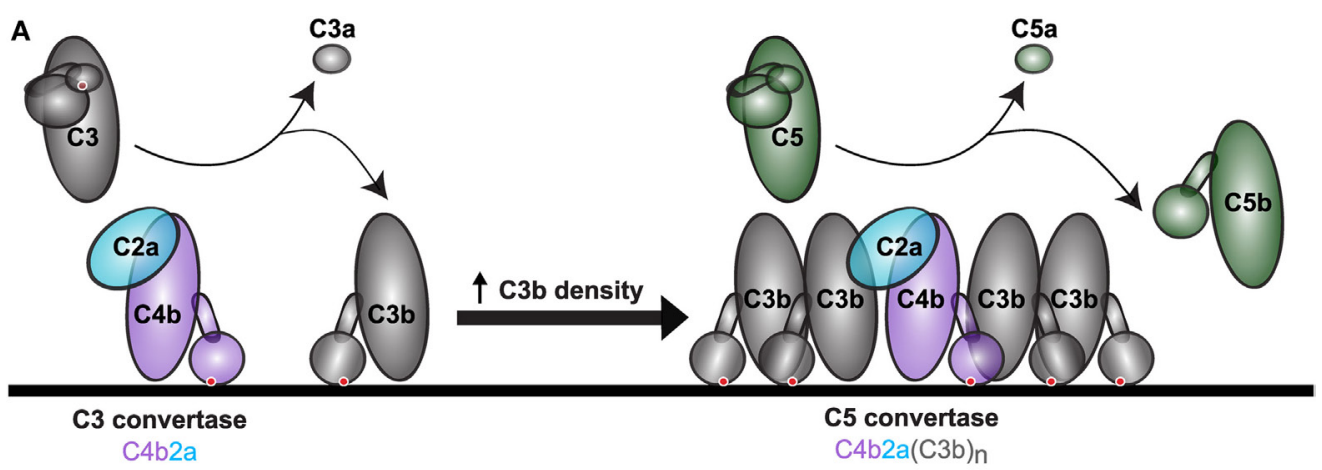

B

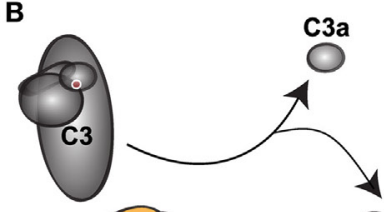

$3 a \quad c 5 a$

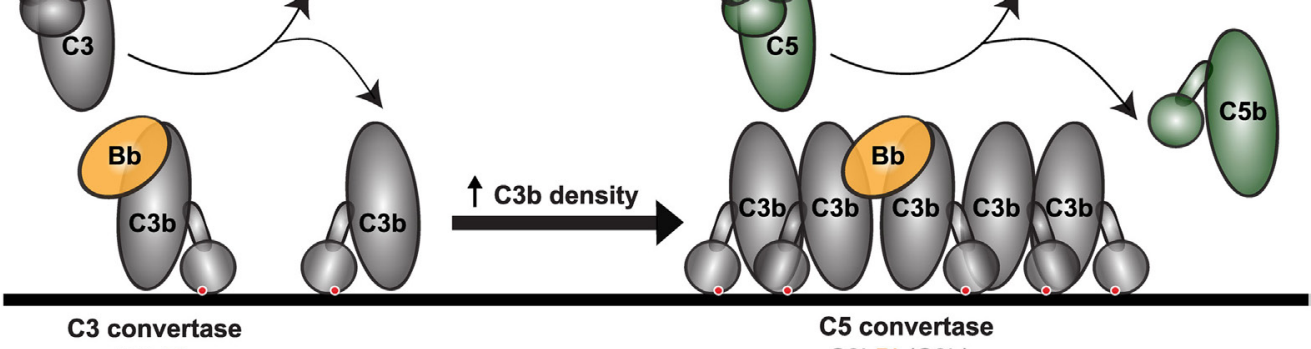

$\mathrm{C} 3 \mathrm{bBb}$

$\mathrm{C} 3 \mathrm{bBb}(\mathrm{C} 3 \mathrm{~b}) \mathrm{n}$

C

C before cleavage

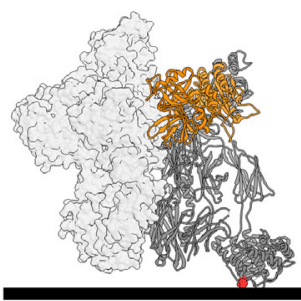

$\mathrm{C} 3: \mathrm{c} 3 \mathrm{bBb}$ after cleavage

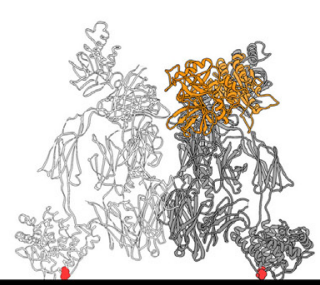

$\mathrm{C} 3 \mathrm{~b}: \mathrm{C} 3 \mathrm{bBb}$
D

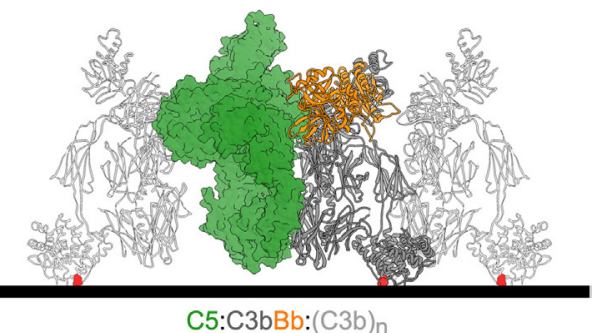

FIGURE 1 | Complement convertases mediate C3 and C5 conversion. (A) Upon complement activation, C3 convertases consisting of either C4b2a (CP and LP) or (B) C3bBb [alternative pathway (AP)] form on the cell surface. Conversion of C3 results in deposition of C3b molecules via the thioester (red dot), which form the basis for new AP convertases (amplification loop) or associate with existing C3 convertases to form C5 convertases. These accessory C3b molecules (C3bn) enable efficient C5 conversion, however, the molecular mechanisms underlying this process are not clear. Shown are C4b (purple), C2a (blue), C3 and cleavage products $\mathrm{C3b} / \mathrm{C} 3 \mathrm{a}$ (gray), Factor B (orange), C5 and cleavage products C5b/C5a (green). (C) Structural models of the C3 convertase C3bBb with its substrate C3 before and after cleavage. Models are based on structures of the C3bBb-SCIN dimer (PDB: 2WIN). The convertase is shown in ribbon representation, with C3b in dark gray and $\mathrm{Bb}$ in orange. On the left, the substrate C3 (light gray surface) is shown before cleavage. On the right, the product C3b (light gray licorice) is shown after cleavage. The red dots highlight the thioester. (D) Structural model of the previously proposed AP C5 convertase with its substrate C5. At a high density of C3b molecules, $\mathrm{C} 5$ is recruited to the target surface and can be cleaved after binding of $\mathrm{Bb}$ to $\mathrm{C} 3 \mathrm{~b}$. The exact molecular arrangement of the $\mathrm{C} 5$ convertases remains unknown. This structural model is based on the CVF-C5 crystal structure (PDB: 3PVM), with accessory C3b molecules added manually surrounding the convertase and C5. CVF (cobra venom factor) is a C3b homolog that lacks the thioester domain and forms stable C5 convertases when associated with Bb in solution. Structure is shown in ribbon representation with C3b (dark gray), Bb (orange), accessory C3b molecules (light gray licorice), and C5 (green surface). 
pathway also forms C4b2a via activation of mannose-binding lectin-associated serine proteases. The resulting CP/LP C4b2a convertases cleave $\mathrm{C} 3$ into $\mathrm{C} 3 \mathrm{a}$ and $\mathrm{C} 3 \mathrm{~b}$. Following cleavage, a reactive thioester in $\mathrm{C} 3 \mathrm{~b}$ is exposed, which enables its covalent attachment to target cell surfaces, leading to recognition of the cells by phagocytes. The labeling of target cells with $\mathrm{C} 3 \mathrm{~b}$ is amplified by the alternative pathway (AP) in which surfacebound $\mathrm{C} 3 \mathrm{~b}$ binds factor $\mathrm{B}(\mathrm{FB})$. The proconvertase $\mathrm{C} 3 \mathrm{bB}$ is then cleaved by factor D (FD) to form an active C3 convertase complex that consists of $\mathrm{C} 3 \mathrm{~b}$ and the protease fragment $\mathrm{Bb}(\mathrm{C} 3 \mathrm{bBb})$ (Figure 1B). Since the resulting active AP C3 convertase $(\mathrm{C} 3 \mathrm{bBb})$ is comprised of $\mathrm{C} 3 \mathrm{~b}$ itself, substrate cleavage results in generation of additional convertases, further propagating $\mathrm{C} 3 \mathrm{~b}$ deposition (Figure 1B). When the density of C3b molecules on the cell surface becomes sufficiently high, the existing C3 convertases $(\mathrm{C} 4 \mathrm{~b} 2 \mathrm{a}$ and $\mathrm{C} 3 \mathrm{bBb})$ gain the ability to cleave $\mathrm{C} 5$, leading to formation of $\mathrm{C} 5 \mathrm{a}$ and C5b (Figures 1A,B) $(7,8)$.

Selective inhibition of $\mathrm{C} 3$ and $\mathrm{C} 5$ convertases is of great therapeutic interest. Most complement inhibitors currently used in the clinic or in clinical development target precursor (not yet activated) complement proteins, that circulate through the body and do not mediate complement effector functions (4). Due to high concentrations of these precursor proteins, effective therapeutic concentrations of complement inhibitors are often quite high, and clearance of these molecules is enhanced due to rapid turnover of complement proteins. Furthermore, saturation of precursor proteins is more likely to systemically suppress complement activation, leading to increased susceptibility to infection (4). Such therapies would be more effective if they specifically targeted active protein complexes like convertases that are primarily formed during complement activation on target cell surfaces. While some therapeutic molecules inhibit convertase function, these likely inhibit multiple convertase enzymes and block all effector functions of complement (4). In some cases, specific inhibition of C5 convertases is desirable for complement therapy, since blocking these would prevent unwanted formation of the major inflammatory trigger $\mathrm{C} 5 \mathrm{a}$ but leave $\mathrm{C} 3 \mathrm{~b}$ deposition via $\mathrm{C} 3$ convertases intact and thus phagocytosis of bacteria. However, the molecular details of C5 convertase formation and C5 cleavage remain poorly understood, largely due to the transient nature of convertases and the fact that efficient C5 conversion is constrained to cell surfaces $(7,9)$. Several earlier studies successfully investigated individual convertases in purified or semi-purified environments (10-14), however, no single model can fully characterize activity and inhibition of both AP and CP C3 and C5 convertases in a purified and controlled environment. Herein, we extended our recently developed model system for AP C5 convertases (7) to also study surface-bound AP C3 convertases, in order to screen for specific inhibitors of convertase enzymes. Furthermore, we developed functional analyses to study CP C3 and C5 convertases using purified complement proteins. Using these models, we can evaluate how known complement inhibitors affect $\mathrm{C} 3 / \mathrm{C} 5$ conversion. In these analyses, we included bacterial and therapeutic complement inhibitors, and human complement regulatory proteins that protect healthy tissue from complement attack $(8,15-18)$. The analyses reveal that several C3b-binding molecules can discriminate between C3 and C5 convertases, suggesting that it is possible to develop more specific convertase inhibitors in the future. Through comparison of our inhibitory data with previously reported structural and biochemical data, we further postulate molecular models of convertase formation.

\section{MATERIALS AND METHODS}

\section{Complement Proteins}

C3 and C5 were prepared from human plasma as previously described (7). For CP assays and inhibitor dose-response assays, recombinant $\mathrm{C} 5$ was used. C5 with a C-terminal His-tag was therefore cloned from gBlocks (Integrated DNA Technologies) using Gibson assembly (Gibco), expressed in HEK293 cells (U-Protein Express, Utrecht, The Netherlands) and purified on a HisTrap column (GE Healthcare). $\mathrm{C}_{3} \mathrm{~b}_{\mathrm{H} 2 \mathrm{O}}$ and C3b-PEG11biotin were prepared as previously described using $180 \mu \mathrm{g} / \mathrm{ml}$ maleimide-PEG11-biotin for the latter (Thermo Scientific Pierce Protein Research, IK, USA) (7). Methylamine-treated C3 (C3 MA $_{\text {) }}$ was prepared by mixing $2.7 \mu \mathrm{M} \mathrm{C} 3$ with $300 \mathrm{mM}$ methylamine hydrochloride (Sigma Aldrich) in $\mathrm{VBS}^{++}$buffer (Veronal Buffered Saline $\mathrm{pH} 7.4,0.25 \mathrm{mM} \mathrm{MgCl}_{2}, 0.5 \mathrm{mM} \mathrm{CaCl}_{2}$ ). This reaction was incubated at $37^{\circ} \mathrm{C}$ for $1 \mathrm{~h}$ and dialyzed overnight to $\mathrm{VBS}^{++}$ buffer at $4^{\circ} \mathrm{C}$. FB with $\mathrm{N}$-terminal His-tag and FD were expressed recombinantly as previously described (U-Protein Express, Utrecht, The Netherlands) (7). C4 was isolated from blood from a healthy individual that was anti-coagulated with $20 \mathrm{mM}$ EDTA. Plasma was collected and protease inhibitors $(10 \mathrm{mM}$ benzamidine, $1 \mathrm{mM}$ PMSF, $7.5 \mu \mathrm{M}$ SBTI, EDTA $5 \mathrm{mM}$, $2.1 \mathrm{mM}$ Pefabloc $\mathrm{SC}, 30 \mu \mathrm{M}$ NPGB) were added quickly, while stirring the plasma at $4^{\circ} \mathrm{C}$. To remove large complexes, plasma was precipitated with 4\% PEG 6000, which was added slowly to the plasma for $45 \mathrm{~min}$. After centrifugation, the supernatant was isolated from which plasminogen was removed by adding $20 \mathrm{mM}$ EDTA and Lysine-Sepharose and incubation for $1 \mathrm{~h}$ at $4^{\circ} \mathrm{C}$. From the supernatant, $\mathrm{C} 4$ was isolated by SourceQ anion exchange. Loading was performed in $50 \mathrm{mM}$ Tris- $\mathrm{HCl}, 100 \mathrm{mM} \mathrm{NaCl}, \mathrm{pH}$ 8.0 (containing $1 \mathrm{mM}$ benzamidine, $1 \mathrm{mM}$ PMSF, $30 \mathrm{mM}$ EACA, and $5 \mathrm{mM}$ EDTA) after which $\mathrm{C} 4$ was eluted in a gradient of $100-500 \mathrm{mM} \mathrm{NaCl}$ in $50 \mathrm{mM}$ Tris- $\mathrm{HCl}, 100 \mathrm{mM} \mathrm{NaCl}, \mathrm{pH} 8.0$ (containing $1 \mathrm{mM}$ benzamidine, $1 \mathrm{mM}$ PMSF, $30 \mathrm{mM}$ EACA, and $5 \mathrm{mM}$ EDTA). Fractions were analyzed by $10 \%$ SDS-PAGE following Instant Blue (Roche) protein staining according to the manufacturer's instructions. C2 with a N-terminal His-tag was expressed in HEK293 cells stably expressing EBNA1 (HEK293E) as described (U-Protein Express, Utrecht, The Netherlands) (19). C2 was purified from expression medium via immobilized metal affinity chromatography using a HisTrap column (GE Healthcare). C1 was obtained from Complement Technology Inc. (TX, USA).

\section{Complement-Binding Molecules and Proteins}

$\mathrm{FH}$ and $\mathrm{C} 4 \mathrm{~b}$-binding protein (C4BP) were ordered via Complement Technology Inc. (Tyler, TX, USA). FHR5 was purchased at R\&D systems (Minneapolis, MN, USA). Eculizumab was 
obtained via Genmab (Utrecht, The Netherlands). Cp40 was kindly provided by John Lambris. CRIg was kindly provided by Genentech (South San Francisco, CA, USA). OmCI was produced in HEK293E cells and purified as described previously (20). Efb-C and Efb-C mutant (Efb-C-R131E/N138E) were prepared as previously described $(21,22)$, as well as Ecb, Ecb mutant (EcbN63E/R75E/N82E) (23), and SSL7 (24).

\section{Human Monoclonal Antibodies}

Monoclonal human anti-DNP-IgG1 was produced recombinantly in human Expi293F cells (Life Technologies). Therefore, the variable region of the heavy chain (>VH7007-DNP-G2a2: DVRLQESGPGLVKPSQSLSLTCSVTGYSITNSYYWNWIRQF P GN KLEW MVYIG Y D G SN NYN P S L KNRISITRD T SKNQFFLKLNSVTTEDTATYYCARATYYGNYRGFAYWGQ GTLVTVSA) and light chain (>VL7007-DNP-G2a2: DIRMTQT TSSLSASLGDRVTISCRASQDISNYLNWYQQKPDGTVKLLIY YTSRLHSGVPSRFSGSGSGTDYSLTISNLEQEDIATYFCQQG NTLPWTFGGGTKLEIK) (25) were cloned in the pFUSE-CHIghG1 and pFUSE2-CLIg-hk vector, respectively, according to the manufacturer's description (Invivogen). A KOZAK sequence and the HAVT20 signal peptide (MACPGFLWALVISTCLEFSMA) were included upstream each variable region. Human codon optimized sequences were ordered as gBlocks (Integrated DNA Technologies) for Gibson assembly (Bioke). TOP10F' E. coli were used for propagation of the plasmids. After sequence, verification plasmids were isolated using NucleoBond Xtra Midi plasmid DNA purification (Macherey-Nagel). Transfection of EXPI293F cells was performed using ExpiFectamine 293 reagent according to the manufacturer's description (Life Technologies). $1 \mu \mathrm{g}$ DNA/ $\mathrm{ml}$ cells was used in a 3:2 (hk:hG1) ratio. Cell supernatant was collected after 4 days of transfection and antibodies were isolated using a HiTrap protein A column (GE Healthcare).

\section{U937 Cell Lines}

U937 human monocyte cells and 293 T human embryonic kidney cells were obtained from American Type Culture Collection and grown $\left(37^{\circ} \mathrm{C}, 5 \% \mathrm{CO}_{2}\right)$ in RPMI (Lonza) supplemented with penicillin and streptomycin (Gibco) and 10\% FCS (Gibco). For stable expression of human C3aR in U937 cells, a lentiviral expression system was used. The human C3aR cDNA was cloned in a dual promoter lentiviral vector, derived from no. 2025.pCCLsin.PPT.pA.CTE.4x-scrT.eGFP.mCMV.hPGK. NGFR.pre (kindly provided by Dr. Luigi Naldini, San Raffaele Scientific Institute, Milan, Italy) as previously described (26). This altered lentiviral vector (BIC-PGK-Zeo-T2a-mAmetrine; EF1A) uses the human EF1A promoter to facilitate potent expression in immune cells and expresses the fluorescent protein $\mathrm{mAmetrine}$ and selection marker ZeoR. Virus was produced in 24-well plates using standard lentiviral production protocols and the third-generation packaging vectors pMD2G-VSVg, pRSV-REV, and pMDL/RRE. Briefly, $0.25 \mu \mathrm{g}$ lentiviral vector and $0.25 \mu \mathrm{g}$ packaging vectors were co-transfected in $293 \mathrm{~T}$ cells by using $1.5 \mu \mathrm{l}$ Mirus LT1 tranfection reagent (Sopachem, Ochten, The Netherlands). After 72 h, $100 \mu$ l viral supernatant adjusted to $8 \mathrm{mg} / \mathrm{ml}$ polybrene was used to infect $\sim 50,000 \mathrm{U} 937$ cells by spin infection at $1,000 \mathrm{~g}$ for $2 \mathrm{~h}$ at $33^{\circ} \mathrm{C}$. U937-C5aR cells were a generous gift from Eric Prossnitz (University of New Mexico, Albuquerque, NM, USA).

\section{C3 and C5 Conversion in AP Model}

Streptavidin-coated magnetic beads (Dynabeads M-270 Streptavidin, Invitrogen) were washed once in VBS-T/Mg [Veronal Buffered Saline pH 7.4, $2.5 \mathrm{mM} \mathrm{MgCl}_{2}, 0.05 \%$ (v/v) Tween]. To prepare fully loaded C3b-beads, beads ( $4 \mu \mathrm{l} /$ sample) were resuspended in $0.4 \mathrm{ml} \mathrm{VBS-T/Mg}$ per sample with C3b-PEG11biotin $(1 \mu \mathrm{g} / \mathrm{ml})$ and incubated for $1 \mathrm{~h}$ at $4^{\circ} \mathrm{C}$ on roller. To load beads with different amounts of $\mathrm{C} 3 \mathrm{~b}$, five different amounts of beads per sample $(4,8,16,32$, or $64 \mu \mathrm{l}$ beads) were incubated in $0.4 \mathrm{ml} \mathrm{VBS}-\mathrm{T} / \mathrm{Mg}$ with $0.6 \mu \mathrm{g} / \mathrm{ml} \mathrm{C} 3 \mathrm{~b}-\mathrm{PEG} 11$-biotin. After C3b-labeling, beads were washed three times and incubated in $100 \mu \mathrm{l} \mathrm{VBS}-\mathrm{T} / \mathrm{Mg}$ per sample with $\mathrm{FB}(50 \mu \mathrm{g} / \mathrm{ml})$ for $30 \mathrm{~min}$ at room temperature on roller. After FB incubation, beads were washed three times and incubated in $100 \mu \mathrm{l} \mathrm{VBS}-\mathrm{T} / \mathrm{Mg}$ per sample with FD $(5 \mu \mathrm{g} / \mathrm{ml})$ and either C3 $(20 \mu \mathrm{g} / \mathrm{ml})$ or C5 $(20 \mu \mathrm{g} / \mathrm{ml})$ and with or without inhibitor at the desired concentration $(1 \mu \mathrm{M}$ or threefold dilution starting from $1 \mu \mathrm{M})$ for $1 \mathrm{~h}$ at $37^{\circ} \mathrm{C}$ on shaker. After incubation, supernatant of each sample was collected and kept at $-20^{\circ} \mathrm{C}$ until measurement in calcium mobilization assay.

\section{C3 and C5 Conversion in CP Model}

Streptavidin-coated magnetic beads (Dynabeads M-270 Streptavidin, Invitrogen) were washed once in PBS-TH [Phosphate Buffered Saline pH 7.4, 0.05\% (v/v) Tween, 0.5\% HSA]. Beads ( $4 \mu \mathrm{l} /$ sample) were resuspended in $0.4 \mathrm{ml} \mathrm{PBS}$-TH per sample with $1 \mu \mathrm{g} / \mathrm{ml}$ biotinylated 2,4-dinitrophenol [DNP-PEG2-GSGS GSGK(Biotin)-NH2; 1,186 Da; obtained from Pepscan Therapeutics B.V., The Netherlands] and incubated for $30 \mathrm{~min}$ at $4^{\circ} \mathrm{C}$ on roller. Beads were washed once in PBS-TH and incubated in $0.2 \mathrm{ml}$ PBS-TH per sample with $10 \mathrm{nM}$ human monoclonal anti-DNP-IgG1 for $30 \mathrm{~min}$ at $4^{\circ} \mathrm{C}$ on roller.

After one wash in PBS-TH, beads were incubated in $0.1 \mathrm{ml}$ $\mathrm{VBS}^{++}$-TH [Veronal Buffered Saline $\mathrm{pH} 7.4,0.25 \mathrm{mM} \mathrm{MgCl}_{2}$, $0.5 \mathrm{mM} \mathrm{CaCl}_{2}, 0.05 \%$ (v/v) Tween, $0.5 \% \mathrm{HSA}$ ] per sample with $0.8 \mu \mathrm{g} / \mathrm{ml} \mathrm{C} 1$ for $30 \mathrm{~min}$ at $37^{\circ} \mathrm{C}$, shaking. Beads were washed three times in $\mathrm{VBS}^{++}-\mathrm{TH}$ and incubated in $0.1 \mathrm{ml} \mathrm{VBS}{ }^{++}-\mathrm{TH}$ per sample with $10 \mu \mathrm{g} / \mathrm{ml} \mathrm{C} 4$ for $30 \mathrm{~min}$ at $37^{\circ} \mathrm{C}$, shaking. After three washes in $\mathrm{VBS}^{++}-\mathrm{TH}$, beads were incubated in $0.1 \mathrm{ml} \mathrm{VBS}{ }^{++}-\mathrm{TH}$ per sample with $10 \mu \mathrm{g} / \mathrm{ml} \mathrm{C} 2,10 \mu \mathrm{g} / \mathrm{ml} \mathrm{C} 3$, and $0.5 \mu \mathrm{g} / \mathrm{ml} \mathrm{C5}$ with or without $1 \mu \mathrm{M}$ inhibitor for $5 \mathrm{~min}$ at $37^{\circ} \mathrm{C}$ on shaker. After incubation, the supernatant of each sample was collected and kept at $-20^{\circ} \mathrm{C}$ until measurement in calcium mobilization assay.

In some $\mathrm{CP}$ experiments, the amount of deposited $\mathrm{C} 3 \mathrm{~b}$ was influenced by adding lower concentrations of C3 (threefold decrease starting from $10 \mu \mathrm{g} / \mathrm{ml}$ ). In one condition, C3 and C5 conversion were separated by incubating beads first in $0.1 \mathrm{ml} \mathrm{VBS}{ }^{++}-\mathrm{TH}$ per sample with $10 \mu \mathrm{g} / \mathrm{ml} \mathrm{C} 2$ and $10 \mu \mathrm{g} / \mathrm{ml}$ $\mathrm{C} 3$ for $5 \mathrm{~min}$ at $37^{\circ} \mathrm{C}$ and subsequently, after washing, in $0.1 \mathrm{ml}$ $\mathrm{VBS}^{++}-\mathrm{TH}$ with $10 \mu \mathrm{g} / \mathrm{ml} \mathrm{C} 2$ and $0.5 \mu \mathrm{g} / \mathrm{ml} \mathrm{C} 5$ for $5 \mathrm{~min}$ at $37^{\circ} \mathrm{C}$. Supernatant of both $\mathrm{C} 2+\mathrm{C} 3$ and $\mathrm{C} 2+\mathrm{C} 5$ incubation were here collected and used for calcium mobilization in U937-C3aR and U937-C5aR cells, respectively. Controls were carried out with $10 \mu \mathrm{g} / \mathrm{ml} \mathrm{C} 3 \mathrm{~b}_{\mathrm{H} 2 \mathrm{O}}$ or $10 \mu \mathrm{g} / \mathrm{ml} \mathrm{C} 3_{\mathrm{MA}}$. 


\section{Calcium Mobilization Assay With U937 Cells}

U937-C3aR and U937-C5aR cells were washed in RPMI/0.05\% HSA and diluted to $5 \times 10^{6}$ cells $/ \mathrm{ml}$. Cells were incubated with $0.5 \mu \mathrm{M}$ Fluo-3-AM (Invitrogen) on roller in dark at room temperature for $20 \mathrm{~min}$, washed and resuspended in RPMI/1\% HSA to a final concentration of $1 \times 10^{6}$ cells $/ \mathrm{ml}$. For calcium mobilization measurements, the labeled cells were stimulated with sample supernatant (ratio cells to supernatant is 9:1) while cell fluorescence is measured by flow cytometry (BD FACSVerse) from $10 \mathrm{~s}$ before until $40 \mathrm{~s}$ after addition of the sample. The absolute calcium mobilization was calculated by subtracting the cell mean fluorescence intensity (MFI) before cell activation $(t=5-15 \mathrm{~s})$ from the MFI after stimulation $(t=30-50 \mathrm{~s})$ using FlowJo software. Standard curves were obtained using 10-fold dilutions starting from $1 \mu \mathrm{M}$ of C3a (Complement Technology Inc., TX, USA) or C5a (Bachem, Switzerland) as stimuli for the cells. As negative controls the calcium mobilization in U937C3aR and U937-C5aR cells induced by $0.1 \mu \mathrm{M}$ C3 or C5 was measured.

\section{C3b Binding to Beads}

To determine the level of $\mathrm{C} 3 \mathrm{~b}$-biotin bound to streptavidincoated beads in the AP model or the level of actively deposited $\mathrm{C} 3 \mathrm{~b}$ in the $\mathrm{CP}$ model, beads were washed three times in PBS-T (AP) or PBS-TH (CP) after the C3b-biotin or C3 incubation and incubated ( $4 \mu \mathrm{l}$ beads/sample) in $100 \mu \mathrm{l}$ PBS-TH per sample with 1:100 FITC-conjugated goat-anti-human C3 (Protos) for $30 \mathrm{~min}$ at $4^{\circ} \mathrm{C}$. Subsequently, beads were washed three times in PBS-T (AP) or PBS-TH (CP) and $\mathrm{C} 3 \mathrm{~b}$ binding was analyzed by flow cytometry (BD FACSVerse).

\section{Statistical Analysis}

Statistical analysis was performed with GraphPad Prism 6 software. All calcium flux data are presented as mean \pm SD from three independent experiments. $\mathrm{C} 3 \mathrm{~b}$ binding data are presented as geometric mean \pm SD from three independent experiments.

\section{RESULTS}

\section{Functional Analysis of C3 Conversion via Purified AP Convertases}

Previously, we described the development of a model system to study C5 convertases of the AP using purified components (7). The AP C5 convertase is formed when $\mathrm{C} 3$ convertases $(\mathrm{C} 3 \mathrm{bBb})$ cleave $\mathrm{C} 3$ into nascent $\mathrm{C} 3 \mathrm{~b}$ that covalently binds to target surfaces via the thioester (structural model in Figure 1C) (27). At a critical density of $\mathrm{C} 3 \mathrm{~b}$ molecules, multimeric $\mathrm{C} 3 \mathrm{~b}_{\mathrm{n}}$ complexes arise that have a high affinity for $\mathrm{C} 5$. These $\mathrm{C} 3 \mathrm{~b}_{\mathrm{n}}$ complexes, together with $\mathrm{FB}$ and $\mathrm{FD}$, generate $\mathrm{C} 5$ convertases that bind and cleave C5 (Figure 1D). We recently set out to mimic surface-bound high C3b-density using purified proteins. To establish this, we first labeled $\mathrm{C} 3 \mathrm{~b}$ with biotin via the thioester by activating plasmapurified $\mathrm{C} 3$ into $\mathrm{C} 3 \mathrm{~b}$ in the presence of a biotinylation agent that reacts with the cysteine residue of the C3b thioester (28). These biotinylated C3b molecules were subsequently loaded onto small magnetic streptavidin (SA) beads $(2.8 \mu \mathrm{m}$ diameter $)$ and incubated with FB and FD to form surface-bound convertases. C5 conversion was examined by quantifying the release of C5a using a flow cytometry-based calcium mobilization assay $(29,30)$. In short, U937 cells transfected with the C5a receptor (U937-C5aR) were exposed to sample supernatants containing $\mathrm{C} 5 \mathrm{a}$. Binding of $\mathrm{C} 5 \mathrm{a}$ to the $\mathrm{C} 5 \mathrm{a}$ receptor mediates intracellular calcium release, which is detected by a fluorescent indicator. To get more insights into convertase formation and inhibition, we here extended this model to also study C3 conversion by purified AP convertases. First, we transfected U937 cells with the $\mathrm{C} 3 \mathrm{a}$ receptor (U937-C3aR) and showed that purified C3a, but not C3, successfully triggers the mobilization of intracellular calcium in U937-C3aR cells (Figure 2A). Low-level activation by purified $\mathrm{C} 5 \mathrm{a}$ is likely due to low levels of endogenous $\mathrm{C} 5 \mathrm{aR}$ expression in these cells (Figure 2A). Second, C3b-coated beads were incubated with FB, FD and C3 and release of C3a was determined in supernatants via calcium mobilization in U937C3aR (Figure 2B). C3a-dependent calcium flux specifically required all convertase components. In our previous study, we determined that high C3b-density is essential to effectively convert C5 (7). By maintaining a constant concentration of $\mathrm{C} 3 \mathrm{~b}$ in each sample while increasing the number of beads, we artificially lowered the local concentration of $\mathrm{C} 3 \mathrm{~b}$ on the surface (Figure S1 in Supplementary Material). Here, we find that while lowering $\mathrm{C} 3 \mathrm{~b}$ surface density reduces $\mathrm{C} 5$ conversion by AP convertases, it does not lead to less $\mathrm{C} 3$ conversion (Figure 2C). These results demonstrate key differences in the conditions required for $\mathrm{C} 3$ and $\mathrm{C} 5$ conversion on a surface in the AP.

\section{Select C3b-Binding Molecules Inhibit AP $\mathrm{C} 5$ but Not $\mathrm{C} 3$ Conversion}

Having established a system to study both C3 and C5 conversion by AP convertases, we could now dissect whether known convertase inhibitory molecules block cleavage of both substrates. We focused on studying C3b- or C5-binding molecules for which the binding sites to $\mathrm{C} 3 \mathrm{~b} / \mathrm{C} 5$ have been determined. Each of these molecules has been extensively characterized in previous studies and is known to influence convertase activity in physiological environments (Table 1). The structures of the $\mathrm{C} 3 \mathrm{~b}$-binding molecules in complex with the $\mathrm{C} 3 \mathrm{bBb}$ convertase are shown in Figure 3A. The inhibitors include naturally occurring complement inhibitors derived from humans [C3b-binders CRIg (31, 32), FH $(33,34)$, and FHR5 (35)], bacteria [homologous C3b-binders Efb-C $(36)$ and Ecb $(16,23)$ and C5-binder SSL7 (37)], and ticks [C5-binder OmCI (20)], or therapeutic inhibitors eculizumab [Soliris, a clinically approved antibody against C5 (38)] and Cp40 [a compstatin analog, strong C3- and C3b-binding molecule (39)]. As expected, we observed that the three C5-binding molecules SSL7, OmCI, and eculizumab specifically interfered with C5 conversion but not C3 conversion (Figure 3B). C4BP (40) was included as a negative control for inhibition, as it should not have an effect on AP C3 or C5 convertases, since these convertases lack C4b (Figure 3B). Next, we analyzed the activity of C3b-binding molecules on $\mathrm{C} 3$ versus 


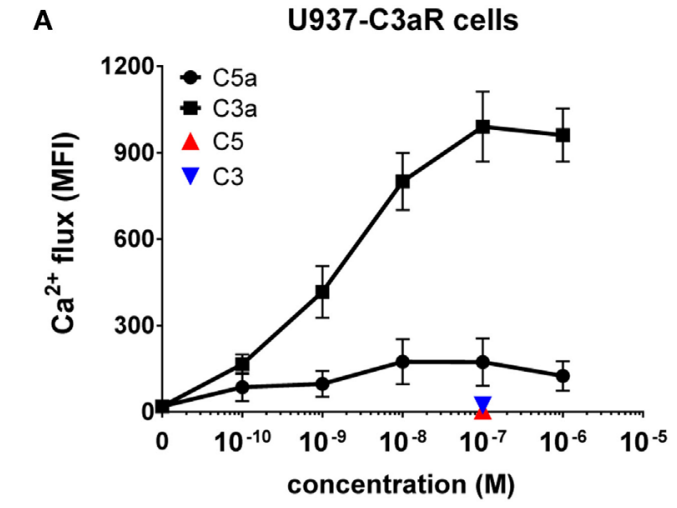

B

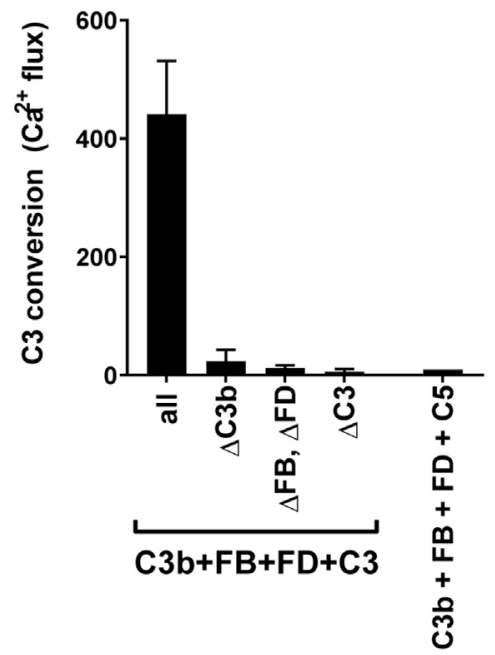

C

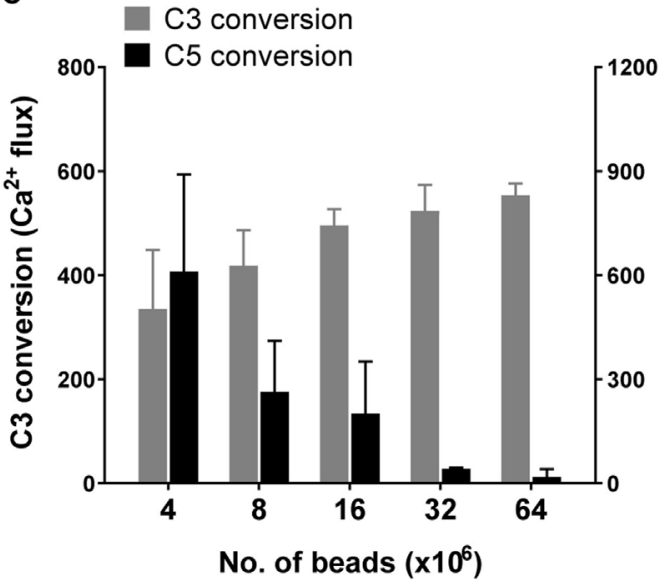

FIGURE 2 | Development of an alternative pathway (AP) C3 convertase model. (A) C3a specifically induces calcium mobilization in U937-C3aR cells, while $\mathrm{C} 3$ and $\mathrm{C} 5$ do not. (B) $\mathrm{C} 3$ conversion by AP convertases on beads was analyzed in a calcium mobilization assay with U937-C3aR cells. C3a could only be detected in the sample supernatant in the presence of all AP components. C5 conversion in the AP model did not induce calcium flux in the U937-C3aR cells. (C) AP C3 and C5 conversion were performed on beads coated with different densities of C3b and analyzed by calcium mobilization assay with U937-C3aR and -C5aR cells, respectively. A high density of C3b molecules on the target surface enhances $\mathrm{C} 5$ but not $\mathrm{C} 3$ conversion. (A-C) Data of three independent experiments, presented as mean $\pm S D$.
TABLE 1 | Overview of complement inhibitors used in this study.

\begin{tabular}{|c|c|c|c|}
\hline Inhibitor & & Type & $\begin{array}{c}\text { Key } \\
\text { references }\end{array}$ \\
\hline \multicolumn{4}{|c|}{ C3b-binding molecules } \\
\hline Cp40 & $\begin{array}{l}\text { Compstatin (analog } \\
\text { Cp40) }\end{array}$ & Cyclic peptide & $(39,41,42)$ \\
\hline CRlg & $\begin{array}{l}\text { Complement receptor } \\
\text { of immunoglobulin family }\end{array}$ & $\begin{array}{l}\text { Human complement } \\
\text { regulator protein }\end{array}$ & $(31,32)$ \\
\hline $\mathrm{FH}$ & Factor $\mathrm{H}$ & $\begin{array}{l}\text { Human complement } \\
\text { regulator protein }\end{array}$ & $\begin{array}{c}(33,34,43 \\
44)\end{array}$ \\
\hline FHR5 & Factor $\mathrm{H}$ related-protein 5 & $\begin{array}{l}\text { Human complement } \\
\text { regulator protein }\end{array}$ & $(35,45)$ \\
\hline Efb-C & $\begin{array}{l}\text { (C-terminal region of }) \\
\text { Extracellular fibrinogen } \\
\text { binding protein }\end{array}$ & $\begin{array}{l}\text { Staphylococcus aureus } \\
\text { immune evasion protein }\end{array}$ & $(21,36,46)$ \\
\hline Ecb & $\begin{array}{l}\text { Extracellular complement } \\
\text { binding protein (also } \\
\text { known as Ehp) }\end{array}$ & $\begin{array}{l}\text { Staphylococcus aureus } \\
\text { immune evasion protein }\end{array}$ & $(16,23)$ \\
\hline \multicolumn{4}{|c|}{ C5-binding molecules } \\
\hline SSL7 & $\begin{array}{l}\text { Staphylococcal } \\
\text { superantigen-like } \\
\text { protein } 7\end{array}$ & $\begin{array}{l}\text { Staphylococcus aureus } \\
\text { immune evasion protein }\end{array}$ & $(37,47,48)$ \\
\hline $\mathrm{OmCl}$ & $\begin{array}{l}\text { Ornithodoros moubata } \\
\text { complement inhibitory } \\
\text { protein }\end{array}$ & $\begin{array}{l}\text { Ornithodoros moubata } \\
\text { immune evasion protein }\end{array}$ & $(20,49,50)$ \\
\hline Eculizumab & Also known as Soliris & $\begin{array}{l}\text { Humanized monoclonal } \\
\text { antibody }\end{array}$ & $(38,51,52)$ \\
\hline \multicolumn{4}{|c|}{ C4b-binding molecules } \\
\hline C4BP & C4b-binding protein & $\begin{array}{l}\text { Human complement } \\
\text { regulator protein }\end{array}$ & $(40,53,54)$ \\
\hline
\end{tabular}

C5 conversion. While C3b-binding molecules Cp40, CRIg, and FH blocked both C3 and C5 conversion by AP convertases, host regulatory protein FHR5, and staphylococcal immune evasion proteins Efb-C and Ecb specifically blocked C5 conversion, while leaving $\mathrm{C} 3$ conversion unaffected (Figure 3C). Mutants of $\mathrm{Efb}-\mathrm{C} / \mathrm{Ecb}$ proteins that cannot bind C3b could not inhibit C5 conversion, confirming that the observed inhibition is mediated through interaction with C3b (Figure 3C) $(21,23)$. Furthermore, Efb-C, Ecb, and FHR5 all inhibit AP C5 conversion in a concentration-dependent manner (Figure 3E), but do not affect C3 conversion (Figure 3D). As a control, we observed that Cp40, which showed inhibition of both AP C 3 and C5 conversion at $1 \mu \mathrm{M}$ concentration, also inhibits both $\mathrm{C} 3$ and $\mathrm{C} 5$ conversion in a concentration-dependent manner (Figures 3D,E). Thus, these data suggest that by binding C3b, selective inhibition of AP C5 convertases is possible. AP C5 convertases are similar to AP C3 convertases, but contain accessory $\mathrm{C} 3 \mathrm{~b}$ molecules $\left(\mathrm{C} 3 \mathrm{~b}_{\mathrm{n}}\right)$ that enable efficient $\mathrm{C} 5$ conversion on surfaces. Since Efb-C, Ecb, and FHR5 only affect C5 (and not C3) conversion, they likely inhibit through affecting accessory $\mathrm{C} 3 \mathrm{~b}$ molecules on the bead surface. However, the fact that AP C3 and C5 convertases both contain $\mathrm{C} 3 \mathrm{~b}$ confounds the ability to independently study the role of accessory C3b molecules in C5 conversion. 


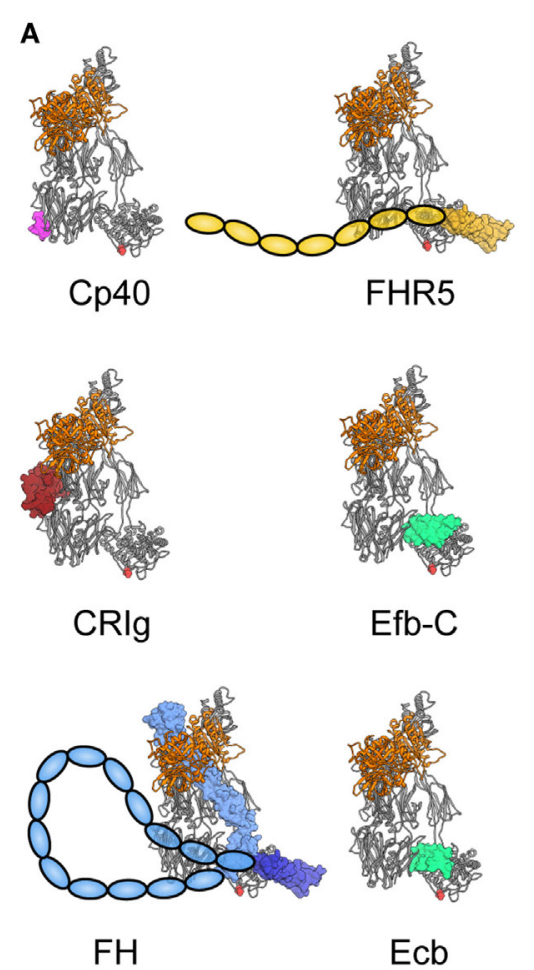

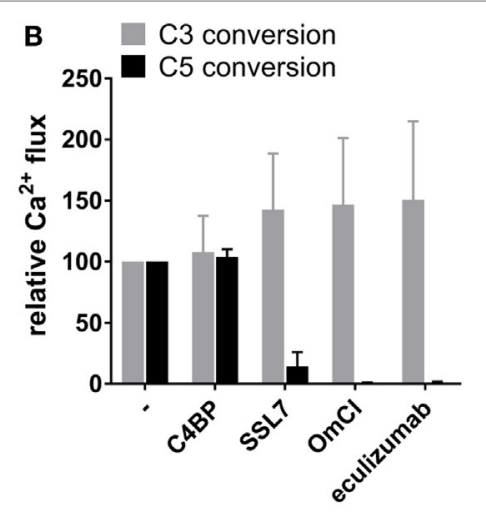

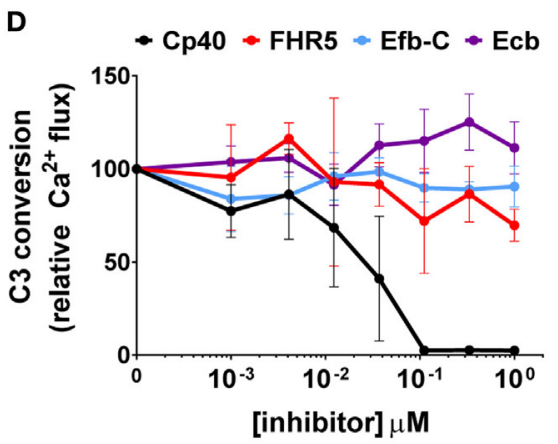

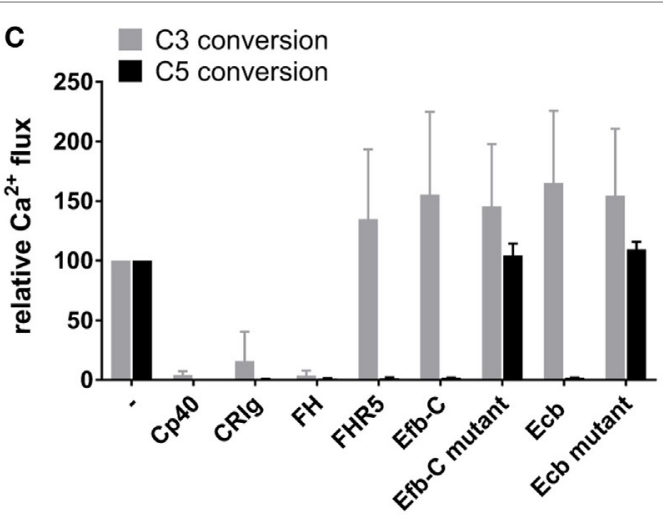

E

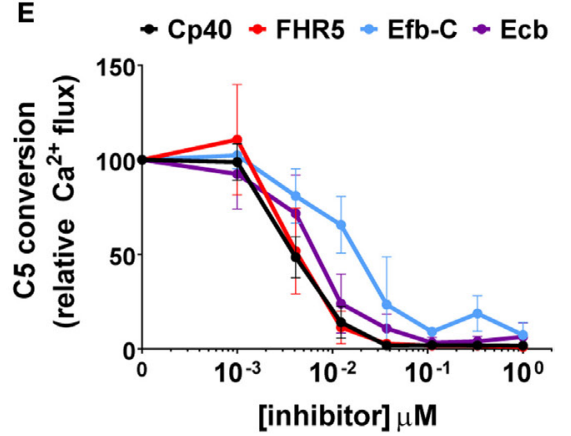

FIGURE 3 | C3b-binding molecules FHR5 and Efb-C/Ecb selectively inhibit C5 conversion by alternative pathway (AP) convertases. (A) Structural models of the $\mathrm{C} 3 \mathrm{bBb}$ convertase with C3b-binding molecules. The structure of C3bBb [from the C3bBb-SCIN dimer structure, PDB 2WIN (55)] is identical to the convertase shown in Figures 1C,D with C3b (gray) and Bb (orange) shown as ribbons, and in the same orientation, with the C3b-C3b dimerization site (as shown in Figure 1C, right) on the left side of the convertase. C3b-binding molecules are shown as molecular surfaces; Cp40 (magenta) is based on the C3c-compstatin complex structure [PDB 2QKI (41)], CRlg (dark red) is based on the C3b-CRlg complex structure [PDB 2ICF (31)], FH is based on the C3b-FH (1-4) structure [light blue, PDB 2WII (43)] and the C3d-FH (19-20) structure [dark blue, PDB 2XQW (44)], FHR5 (yellow) is modeled from the C3d-FH (19-20) structure [PDB 2XQW (44)], Efb-C (spring green) is based on the C3d-Efb-C structure [PDB 2GOX (21)], and Ecb (spring green) is based on the C3d-Ehp structure [PDB 2NOJ (23)]. For FH and FHR5 only some domains are structurally resolved. Additional domains are represented by colored ovals. (B-E) Conversion of C3 and C5 (0.1 $\mu$ M) in the AP convertase model in the presence of complement-binding molecules measured by calcium mobilization in U937-C3aR and U937-C5aR cells, respectively. Conversion is shown as a percentage relative to the control without inhibitor. Data of three independent experiments, presented as mean \pm SD. (B) C5-binding molecules SSL7, OmCl, and eculizumab (all 1 MM) inhibit AP C5 but not C3 conversion. C4b-binding protein has no effect in the AP model. (C) C3b-binding molecules $\mathrm{Cp} 40$, CRlg, and FH prevent both $\mathrm{C} 3$ and C5 conversion, while FHR5, Efb-C, and Ecb selectively inhibit C5 conversion. Mutant Efb-C and mutant Ecb are unable to bind C3b and thus do not exhibit inhibition. (D) FHR5, Efb-C, and Ecb do not affect C3 conversion, but (E) selectively inhibit C5 conversion in a dose-dependent manner. Cp40 was used as positive control, inhibiting both C3 and C5 conversion.

\section{Development of a Purified Classical Pathway C3/C5 Convertase Model}

To more closely investigate convertase inhibitory mechanisms of complement inhibitors, we next developed a model to study $\mathrm{C} 3 / \mathrm{C} 5$ conversion via purified CP convertases. In this pathway, modulation of accessory $\mathrm{C} 3 \mathrm{~b}$ molecules can be better analyzed since the CP C3 convertase (C4b2a) does not contain C3b. We have used a model that fully recapitulates the $\mathrm{CP}$ activation pathway using purified complement components. Streptavidin beads were labeled with biotinylated DNP antigen (Figure 4A) and sequentially incubated with recombinant human IgG1 recognizing DNP, C1, C4, C2 and substrates C3 and C5. Similar to the AP, we detected the release of $\mathrm{C} 3 \mathrm{a}$ and $\mathrm{C} 5 \mathrm{a}$ in the sample supernatant via calcium mobilization in U937-C3aR and U937-C5aR cells, respectively. The lack of calcium mobilization by the sample supernatants in the absence of DNP, IgG or the individual complement proteins demonstrates the necessity of functional $\mathrm{CP}$ convertases on the bead surface for $\mathrm{C} 3 / \mathrm{C} 5$ cleavage (Figure 4B). Our results also showed that there was no cross-reactivity between mismatched ligands and receptors. The absence of calcium flux in U937-C5aR cells by samples lacking C5 (and thus C5a) showed that C3a generated in these samples does not interfere with $\mathrm{C} 5 \mathrm{a}$ detection. As calcium mobilization levels in U937-C3aR cells were not affected by the presence of C5, interference of C5a with C3a-specific detection could be excluded, as well. Unlike our AP C5 convertase model where we artificially coupled $\mathrm{C} 3 \mathrm{~b}$ to the bead surface, deposition of $\mathrm{C} 3 \mathrm{~b}$ in the $\mathrm{CP}$ could only be established by natural $\mathrm{C} 3$ conversion via C4b2a. By adding different concentrations of C3 to beads with naturally formed $\mathrm{C} 4 \mathrm{~b} 2 \mathrm{a}$ convertases, we influenced the level of $\mathrm{C} 3$ conversion and thus $\mathrm{C} 3 \mathrm{~b}$ deposition on the bead surface (Figures 4C,D). Indeed, CP C5 conversion was highly dependent on the level of deposited C3b (Figure 4E). As a control, we showed that C5 conversion specifically depends 


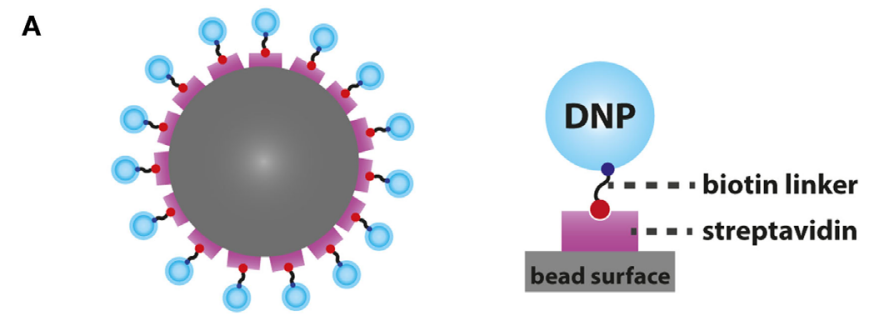

DNP-labeled streptavidin bead

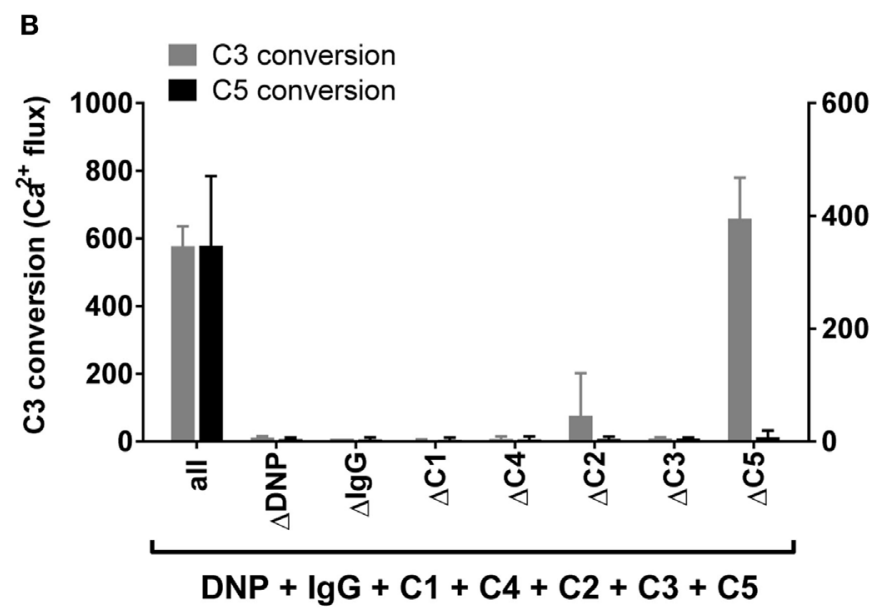

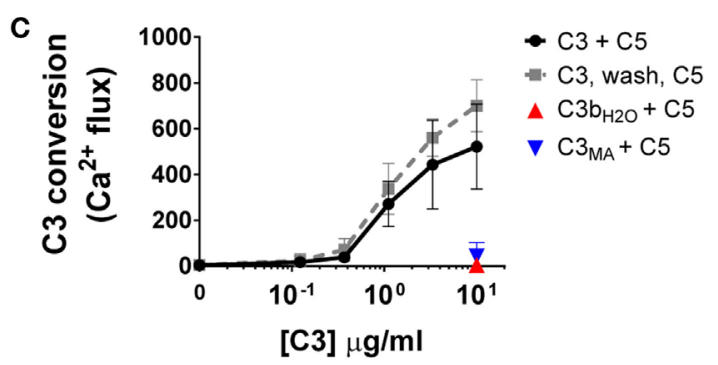

D

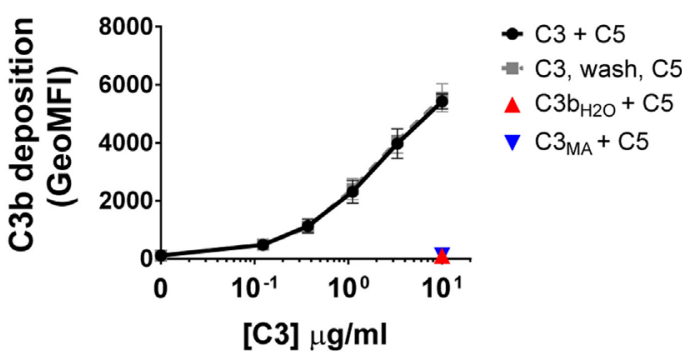

E

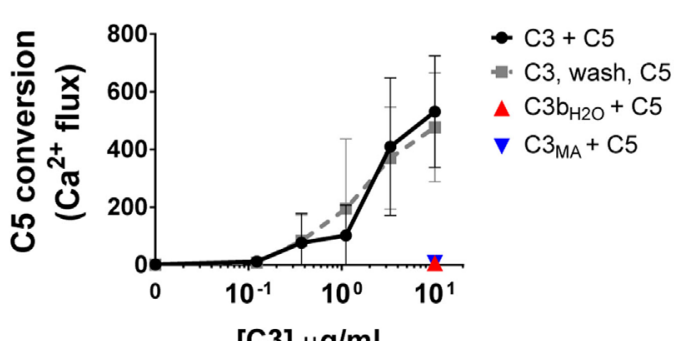

FIGURE 4 | Development of a classical pathway C3 and C5 convertase model. (A) In the CP convertase model, streptavidin beads are labeled with biotinylated DNP which serves as a model antigen. Addition of lgG1 recognizing DNP and complement proteins results in formation of C4b2a and C4b2a(C3b) ${ }_{n}$ convertases on the bead surface, which convert C3 and C5. (B) Only in the presence of all CP components (antigen, IgG, and CP proteins) C3 and C5 are converted, as measured by calcium mobilization in U937-C3aR and U937-C5aR cells, respectively. (C) C3 conversion via CP convertases results in release of C3a in the supernatant (as shown by calcium mobilization) and (D) C3b deposition on the bead surface (as shown by flow cytometry). Identical amounts of the non-reactive C3 variants $\mathrm{C}_{3} \mathrm{~b}_{\mathrm{H} 2 \mathrm{O}}$ and $\mathrm{C}_{\mathrm{MA}}$ do not bind to the bead surface. (E) C5 convertase activity increases with the level of deposited C3b molecules on the beads surface, but is not affected by $\mathrm{C}_{3} \mathrm{~b}_{\mathrm{H} 20}$ or $\mathrm{C}_{\mathrm{MA}}$ in solution. Uncoupling $\mathrm{C} 3$ and $\mathrm{C} 5$ conversion by introduction of an extra washing step does not alter $\mathrm{C} 5$ conversion, indicating that CP C5 conversion only depends on deposited C3b molecules around existing C3 convertases. (B-E) Data of three independent experiments, presented as mean $\pm \mathrm{SD}$.

on covalently deposited $\mathrm{C} 3 \mathrm{~b}$ since addition of non-reactive $\mathrm{C} 3$ variants $\left[\mathrm{C}_{3} \mathrm{~b}_{\mathrm{H} 2 \mathrm{O}}\right.$ in which the thioester had already reacted with water or methylamine-treated $\left.\mathrm{C} 3\left(\mathrm{C} 3_{\mathrm{MA}}\right)(7,56)\right]$ did not induce the convertase to cleave C5 (Figures 4C-E). In addition, introducing a washing step in between $\mathrm{C} 3 \mathrm{~b}$ deposition and $\mathrm{C} 5$ conversion confirmed that only deposited $\mathrm{C} 3 \mathrm{~b}$ and not $\mathrm{C} 3$ or the active process of $\mathrm{C} 3$ cleavage is required for $\mathrm{C} 5$ conversion (Figure 4E). These results demonstrate the specificity of our $\mathrm{CP}$ convertase models in measuring the activity of $\mathrm{CP} \mathrm{C} 3$ and C5 conversion.

\section{C3b-Binding Molecules Inhibit Classical Pathway C5 Conversion by Modulating Accessory C3b}

Next, we examined the effect of the above-tested C3b- and C5-binding molecules in the CP convertase model. Beads with actively formed $\mathrm{C} 4 \mathrm{~b} 2 \mathrm{a}$ convertases were incubated with $\mathrm{C} 2, \mathrm{C} 3$, and $\mathrm{C} 5$ in the presence of complement binding molecules at a concentration of $1 \mu \mathrm{M}$ and the $\mathrm{C} 3 \mathrm{a} / \mathrm{C} 5 \mathrm{a}$ generated in the sample supernatant was measured. The known CP convertase inhibitor C4BP effectively inhibited both CP C3 and C5 conversion, confirming the validity of our model (Figure 5A). Furthermore, C5-binding molecules $\mathrm{OmCI}$ and eculizumab potently inhibited CP C5 conversion but left C3 conversion unaffected (Figure 5A). SSL7 also inhibits CP C5 conversion, but to a lesser extent, which could arise from differences in the models or in the C5-binding sites involved in convertase recognition. Since $\mathrm{C} 3 \mathrm{~b}$ is not part of the $\mathrm{CP}$ C3 convertase, we hypothesized that C3b-binding molecules would not influence $\mathrm{C} 3$ conversion in the CP model. Accordingly, most C3b-binding molecules did not affect $\mathrm{C} 3$ conversion, with the exception of $\mathrm{Cp} 40$, which showed potent inhibition (Figure 5B). The lack of C3 conversion in the presence of Cp40 can be explained by its strong affinity for uncleaved C3 causing steric hindrance during $\mathrm{C} 3$ recognition by the convertase (57). Efb-C and Ecb, which can also bind C3, do not inhibit 

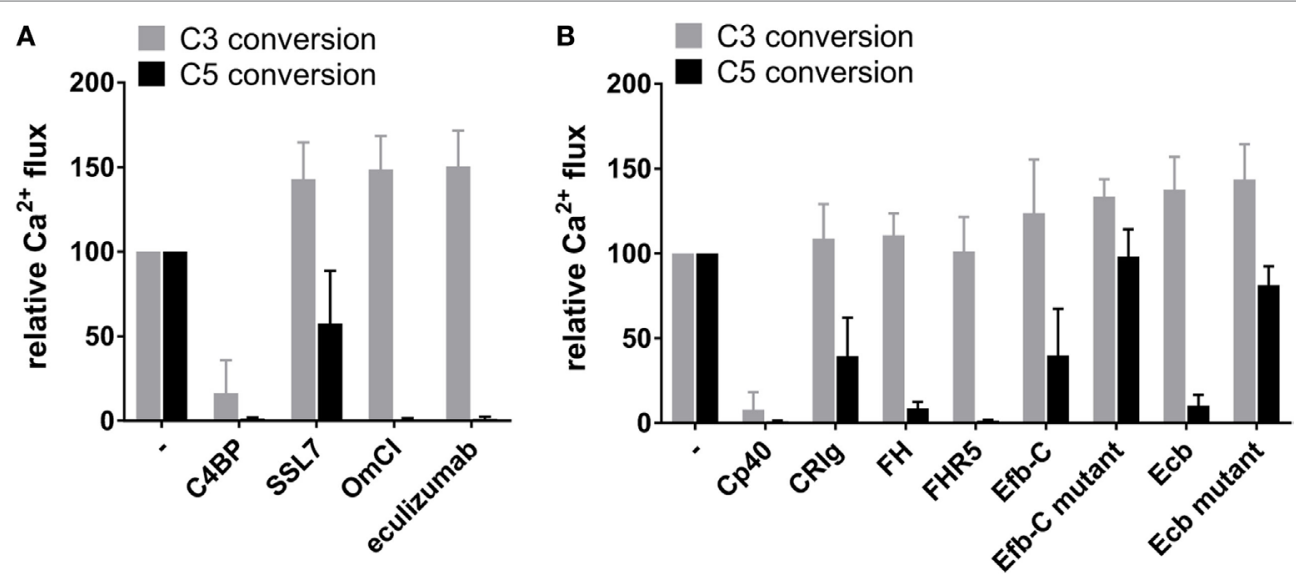

FIGURE 5 | The effect of inhibitors on classical pathway C3 and C5 conversion. Conversion of C3 (50 nM) or C5 (2.5 nM) in the CP model in the absence or presence of $1 \mu \mathrm{M}$ complement-binding molecule measured by calcium mobilization in U937-C3aR and U937-C5aR cells, respectively. Conversion is shown as a percentage relative to the control without inhibitor. (A) C5-binding molecules OmCl and eculizumab inhibit CP C5 but not C3 conversion. SSL7 inhibits C5 conversion, as well, but less efficiently. C4b-binding protein (C4BP) inhibits both CP C3 and C5 convertases. (B) None of the C3b-binding molecules, except for Cp40, affect CP C3 conversion, whereas all inhibit C5 conversion. Mutant Efb-C and mutant Ecb are unable to bind C3b and thus do not exhibit inhibition. $(\mathbf{A}, \mathbf{B})$ Data of three independent experiments, presented as mean $\pm \mathrm{SD}$.

convertase activity in that manner, as further evidenced by lack of inhibition of AP C3 conversion. Interestingly, we found that all C3b-binding molecules can prevent $\mathrm{C} 5$ conversion in the $\mathrm{CP}$ model (Figure 5B). This establishes an important role for accessory C3b in the formation and activity of CP C5 convertases. Moreover, the fact that FHR5, Efb-C, and Ecb exhibited similar effects on $\mathrm{C} 5$ conversion by the AP and CP convertases, indicates a similar role for accessory C3b in C5 conversion in both pathways. The CP model provides more detail about their inhibitory mechanism by showing that they can act specifically via accessory C3b molecules. Similarly, the CP inhibition data show that CRIg and FH can inhibit C5 conversion specifically via accessory C3b. Overall, our data suggest that all C3b-binding molecules tested can inhibit C5 conversion (in both AP and CP) through interaction with accessory $\mathrm{C} 3 \mathrm{~b}$ molecules, but only some can inhibit the core convertase enzyme $(\mathrm{C} 3 \mathrm{bBb})$ itself.

\section{DISCUSSION}

Since C3 and C5 convertase enzymes play such a vital role in propagating the cascade but also driving unwanted complement effector functions, it is essential to better understand mechanisms of convertase activation and inhibition. Since C5 convertases are largely constrained to cell surfaces, it has been difficult to study these enzymes with highly purified complement components. Here, we developed bead-based models to functionally characterize both $\mathrm{C} 3$ and $\mathrm{C} 5$ convertases on a surface using purified components and in the absence of confounding factors from serum. These models serve several important purposes: (1) to understand the molecular biology of convertases, (2) to characterize the mode of action of known complement inhibitors, (3) to characterize the role of disease-associated deficiencies and mutations of complement proteins, and (4) to screen for novel and specific convertase inhibitors.
In the past, several models have been developed to study convertase activation and inhibition. One of the most common models employs erythrocytes to serve as a platform for complement activation, using either serum or stepwise addition of purified complement components. Other studies have employed non-cellular surfaces, including SPR chips, to examine stepwise assembly and dissociation of convertases. While each of these models differ in many aspects, each has inherent advantages and disadvantages in addressing various aspects of complement function, and no single model can capture all molecular and physiological details of convertases or inhibition thereof. Our models offer the ability to (1) quantitatively compare activity and inhibition of AP and CP C3 and C5 convertases independently and (2) enable controlled formation and distribution of convertases in a highly purified environment in the absence of complement regulators found in serum and on cells. In our model, we chose to quantify $\mathrm{C} 3$ and $\mathrm{C} 5$ cleavage through measurement of chemoattractants $\mathrm{C} 3 \mathrm{a}$ and $\mathrm{C} 5 \mathrm{a}$, molecules that are released into solution and can be selectively and sensitively detected in a functional cell-based calcium mobilization assay using flow cytometry. Alternatively, C3a and C5a can be quantified by ELISA, however, this is not a direct functional readout, and one should exercise caution in selecting antibodies with high specificity for each chemoattractant molecule (58). Measurement of C3a via calcium responses allows a more accurate quantification of C3 convertase activity than antibody detection of deposited C3b molecules. During C3 cleavage, the thioester of newly formed $\mathrm{C} 3 \mathrm{~b}$ molecules becomes exposed and can react with molecules on the cell surface. Rapid amplification results in dense clusters of C3b, which may deposit on top of each other, making accurate quantification difficult (59). Furthermore, many newly formed C3b molecules never attach to the surface (60). Therefore, immunodetection of deposited $\mathrm{C} 3 \mathrm{~b}$ is not the best measure of C3 conversion. In addition, since C3a and C5a are 
hallmarks of complement-mediated inflammation, detection of these chemoattractants is a critical readout when screening for convertase inhibitors as potential therapeutic molecules and disease-associated mutants of complement factors in vitro. It is important to note that in more complex environments (i.e., serum or in vivo), measurement of functionally active $\mathrm{C} 3 \mathrm{a} / \mathrm{C} 5 \mathrm{a}$ is challenging due to proteolytic cleavage and scavenging by receptors. In addition, our bead-based models enable additional readouts, including quantification of surface complement deposition and breakdown of complement opsonins through cofactor activity of inhibitory molecules (Figure S2 in Supplementary Material).

The models presented in this work may assist in obtaining better insights into the structural organization of convertase enzymes. While significant progress has been made in understanding the structural organization of $\mathrm{C} 3$ convertases and $\mathrm{C} 3$ cleavage (Figure 1C) (55), the molecular details of C5 convertase formation remain poorly understood. Molecular models of C5 convertase activation have been proposed (Figure 1D) $(47,49,61)$ but the exact organization of this complex remains unknown. It is known that C5 convertases form when C3 convertases (C4b2a and $\mathrm{C} 3 \mathrm{bBb}$ ) deposit high densities of $\mathrm{C} 3 \mathrm{~b}$ molecules on the target surface (9). The non-catalytic subunits of $\mathrm{C} 3$ convertases ( $\mathrm{C} 4 \mathrm{~b}$ or $\mathrm{C} 3 \mathrm{~b}$ ) are thought to associate with extra $\mathrm{C} 3 \mathrm{~b}$ molecules and form multimeric $\mathrm{C} 4 \mathrm{~b}-\mathrm{C} 3 \mathrm{~b}_{\mathrm{n}}$ or $\mathrm{C} 3 \mathrm{~b}-\mathrm{C} 3 \mathrm{~b}_{\mathrm{n}}$ complexes that have an increased affinity for C5 $(62,63)$. In this study, we verified the requirement of high C3b densities for C5 conversion. In line with previous data, we also find that $\mathrm{C} 3 \mathrm{~b}$ density affects $\mathrm{C} 5$, but not $\mathrm{C} 3$ conversion by AP convertases (7). Interestingly, our data for Efb-C/Ecb and FHR5 also suggest that the orientation of $\mathrm{C} 3 \mathrm{~b}$ molecules on the surface is particularly important for conversion of C5, but not C3. We previously demonstrated that the (natural) surface attachment of $\mathrm{C} 3 \mathrm{~b}$ molecules via the thioester is crucial for efficient conversion of C5 (7). Here, we found that three molecules that interact with the $\mathrm{C} 3 \mathrm{~b}$ thioester domain (TED) (Efb-C, Ecb, and FHR5) selectively inhibit AP and CP C5 convertases, while leaving C3 conversion unaffected. Among examined C3b-binding molecules, this selective inhibition of
C5 conversion in the AP was specific for molecules interacting with the TED of C3b. Several crystallographic structures of $\mathrm{C} 3 \mathrm{~b}$ revealed interdomain interactions between TED and the MG1 domain, which facilitate the prototypical "upright" conformation of $\mathrm{C} 3 \mathrm{~b}$ attached to surfaces via its thioester $(31,43$, 55, 64-69). However, recent electron microscopy data reveal conformational flexibility of $\mathrm{C} 3 \mathrm{~b}$ under different conditions, and in particular, TED can exhibit markedly different positions (70-74). Hydrogen-deuterium exchange experiments demonstrated a conformational change in $\mathrm{C} 3 \mathrm{~b}$ upon $\mathrm{Efb}-\mathrm{C}$ binding to TED, suggesting that Efb-C acts as a wedge to disrupt the TED-MG1 interaction and affects the orientation of $\mathrm{C} 3 \mathrm{~b}$ on the surface (71). Although the exact binding interface of $\mathrm{C} 3 \mathrm{~b}$ and FHR5 is unknown, it does interact with TED (75), and therefore it is possible that FHR5 acts through a similar mechanism. It is unclear whether FHR5 also interacts with other regions of $\mathrm{C} 3 \mathrm{~b}$. Binding of $\mathrm{C} 3 \mathrm{~b}$ by FHR5 is different from that by $\mathrm{FH}$, because FHR5 lacks domains homologous to the $\mathrm{FH}$ $\mathrm{N}$-terminal C3b binding and complement regulatory domains. The results reported here confirm the previously reported lack of solid phase C3 convertase inhibition by FHR5 $(45,76)$, although inhibition of fluid phase $\mathrm{C} 3$ convertase was described (45). Why the C3b orientation is critical for C5 conversion but not $\mathrm{C} 3$ conversion remains to be determined. Potentially it supports the recently proposed model in which $\mathrm{C} 5$ needs to be "sandwiched" in between the C3 convertase and the accessory $\mathrm{C} 3 \mathrm{~b}$ molecule in order to be primed for convertase cleavage (49). One could envision that such "sandwiching" is affected by differently oriented C3b's. Alternatively, C3b orientation may determine how closely $\mathrm{C} 3 \mathrm{~b}$ molecules can pack together. If tightly packed and aligned accessory C3b molecules are required for efficient $\mathrm{C} 5$ conversion, altered orientation may result in decreased conversion of $\mathrm{C} 5$ (Figure 6). The fact that $\mathrm{Efb} / \mathrm{Ecb}$ and FHR5 also inhibit C5 conversion in the CP suggests that the accessory $\mathrm{C} 3 \mathrm{~b}$ molecules have a similar function in the activation of both the CP and AP C5 convertases.

Functional analyses of well-defined complement inhibitors also reveal other important binding interfaces of C3/C5 convertases.
A

\section{No Inhibitor \\ C3b forms "packed" clusters $\left(\mathrm{C} 3 \mathrm{~b}_{\mathrm{n}}\right)$ \\ C5 recruited to surface \\ Convertases can cleave}

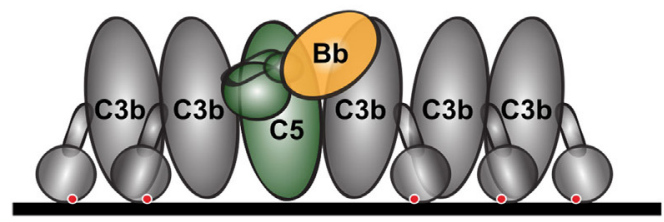

B

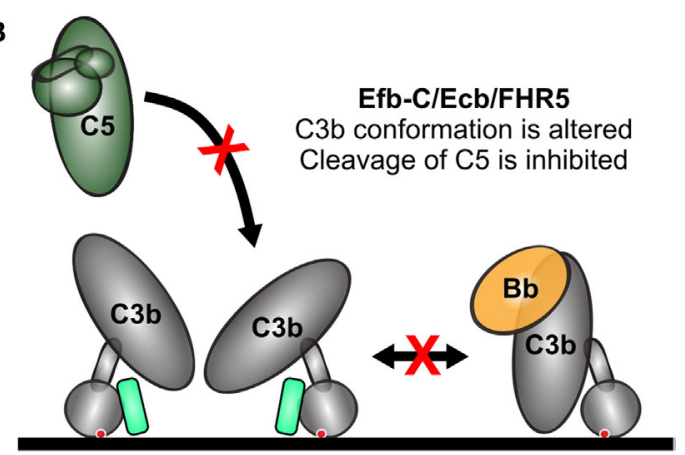

FIGURE 6 | Model for selective inhibition of C5 conversion. (A) Under normal conditions, high levels of accessory C3b (C3b $)$ deposition on a cell surface around existing C3 convertases enables binding and conversion of C5. All C3b molecules are tightly packed and aligned in the same vertical orientation, both of which are necessary for efficient C5 conversion. (B) Thioester domain (TED)-binding molecules (i.e., Efb-C and Ecb) act as a wedge to separate TED from the rest of C3b, which alters its surface conformation and prevents efficient C5 conversion. Colors of molecules correspond to Figures $1 \mathbf{C}, \mathbf{D}$ and $\mathbf{3 A}$, with Efb-C/Ecb shown in spring green. The red crosses indicate inhibition of $\mathrm{C} 5$ and $\mathrm{C} 3 \mathrm{bBb}$ binding to surface-bound accessory C3b molecules (C3b). 
Our model demonstrates that the $\mathrm{C} 3 \mathrm{~b}-\mathrm{C} 3 \mathrm{~b}$ dimerization site (Figure 1C, right) is important for activity of all C3b-containing convertases, including AP C3 and C5 convertases, as well as the CP C5 convertase. The C3b-binding molecules Cp40 and CRIg, which bind at this interface (Figure 3A), universally inhibit activity of C3b-containing convertases. These molecules likely interfere with convertase-substrate binding (as in Figures 1C,D) and/ or surface-bound accessory C3b molecules (as in Figure 1D). Unlike CRIg, Cp40 inhibits all convertases, including the CP C3 convertase, which lacks C3b. Since $\mathrm{Cp} 40$ can bind to both $\mathrm{C} 3 \mathrm{~b}$ and uncleaved $\mathrm{C} 3$, it could inhibit CP C3 conversion by binding to the substrate $(\mathrm{C} 3)$ and preventing recognition by the $\mathrm{CP} \mathrm{C} 3$ convertase $(57,77)$. Substrate C3 binding can also explain the difference in inhibition of AP C3 and C5 conversion by Cp40 (Figures 3D,E). In the AP C3 conversion assay, Cp40 can bind to both $\mathrm{C} 3$ and $\mathrm{C} 3 \mathrm{~b}$, and therefore the concentration required to block C3 conversion is higher than for in the AP C5 conversion assay, where C3 is not present. Next to CRIg, we also found that $\mathrm{FH}$ inhibits $\mathrm{CP} \mathrm{C} 5$ convertases. Although $\mathrm{FH}$ is known as an inhibitor of $\mathrm{AP} \mathrm{C} 3 / \mathrm{C} 5$ convertases because it dissociates $\mathrm{Bb}$ from $\mathrm{C} 3 \mathrm{~b}$, the mechanism of $\mathrm{FH}$-mediated inhibition of $\mathrm{CP}$ C5 conversion is not known. Since FH is a large molecule with several distant binding sites on C3b $(43,44,78)$ it likely interferes with binding $\mathrm{C} 5$ (79). Thus, our data for $\mathrm{FH}$ demonstrate that not only the $\mathrm{C} 3 \mathrm{~b}-\mathrm{C} 3 \mathrm{~b}$ dimerization site, but also other sites on $\mathrm{C} 3 \mathrm{~b}$, are important for its interaction with C5. Overall, C3b-binding molecules illustrate several key properties of convertase assembly and inhibition. While much of the data here are in line with previous inhibitor studies (Table 1), more extensive and complementary studies are required to fully understand the physiological modes of inhibition of these molecules.

Finally, the tools developed in this study can be used for identification of effective therapeutic convertase inhibitors. The ability to examine each convertase separately affords the opportunity to identify selective convertase inhibitors. The complement therapeutics landscape is rapidly expanding, as new roles for complement in disease continue to be uncovered. It is clear that not all complement-mediated diseases are created equal, and it is necessary to design therapeutics that target different points in the complement cascade. For example, diseases mediated

\section{REFERENCES}

1. Walport MJ. Complement. First of two parts. NEnglJ Med (2001) 344:1058-66. doi:10.1056/NEJM200104053441406

2. Ricklin D, Hajishengallis G, Yang K, Lambris JD. Complement: a key system for immune surveillance and homeostasis. Nat Immunol (2010) 11:785-97. doi:10.1038/ni.1923

3. Ricklin D, Lambris JD. Complement in immune and inflammatory disorders: pathophysiological mechanisms. J Immunol (2013) 190:3831-8. doi:10.4049/ jimmunol.1203487

4. Ricklin D, Mastellos DC, Reis ES, Lambris JD. The renaissance of complement therapeutics. Nat Rev Nephrol (2017) 14:26-47. doi:10.1038/nrneph.2017.156

5. Morgan BP, Harris CL. Complement, a target for therapy in inflammatory and degenerative diseases. Nat Rev Drug Discov (2015) 14:857-77. doi:10.1038/ nrd4657

6. Diebolder CA, Beurskens FJ, de Jong RN, Koning RI, Strumane K, Lindorfer MA, et al. Complement is activated by IgG hexamers assembled at the cell surface. Science (2014) 343:1260-3. doi:10.1126/science.1248943 primarily by $\mathrm{C} 5 \mathrm{a}$ or MAC may benefit from selective inhibition of C5 conversion. Blocking the complement cascade upstream of the terminal pathway (i.e., inhibition of C3 cleavage) may unnecessarily increase patient susceptibility to infections by effectively inhibiting all complement effector functions. Our work now demonstrates the characterization of inhibitors that selectively inhibit C5 conversion, which may prove useful in treatment of MAC-mediated and inflammatory disorders of the complement system. Thus, these models provide a platform for the identification of tailored next-generation complement therapeutics.

\section{AUTHOR CONTRIBUTIONS}

SZ, EB, and SR designed and developed convertase models. SZ, $\mathrm{EB}, \mathrm{SR}$, and RG designed the study and experiments. SZ, SM, $\mathrm{MR}$, and RG performed the experiments and analyzed data. $\mathrm{CH}$ developed cell lines. $\mathrm{CH}$ and PA cloned and produced monoclonal antibodies. SZ, SM, SR, and RG wrote the manuscript. SZ, MJ, $\mathrm{SR}$, and RG contributed to critical analysis and discussion of the results. All authors read and reviewed the manuscript.

\section{ACKNOWLEDGMENTS}

We would like to acknowledge John Lambris for providing Cp40, Menno van Lookeren Campagne (Genentech) for providing CRIg, Genmab for providing eculizumab, Brian Geisbrecht for providing constructs for Efb-C and Ecb mutants, U-Protein Express BV (Utrecht, The Netherlands) for help with protein expression, and Kaila Bennett, Bart Bardoel, and Julia Kolata for cloning advice. The work was funded by Marie-Skłodowska Curie Fellowship (659633, to RG); ERC Starting grant (639209-ComBact, to SR), the EMBO Young Investigator Program (to SR); Kidneeds Foundation, Iowa, US (to MJ). MJ was also supported by the Institutional Excellence Program of the Ministry of Human Capacities of Hungary.

\section{SUPPLEMENTARY MATERIAL}

The Supplementary Material for this article can be found online at https://www.frontiersin.org/articles/10.3389/fimmu.2018.01691/ full\#supplementary-material.

7. Berends ETM, Gorham RD, Ruyken M, Soppe JA, Orhan H, Aerts PC, et al. Molecular insights into the surface-specific arrangement of complement C5 convertase enzymes. BMC Biol (2015) 13:93. doi:10.1186/s12915-015-0203-8

8. Merle NS, Church SE, Fremeaux-Bacchi V, Roumenina LT. Complement system part I: molecular mechanisms of activation and regulation. Front Immunol (2015) 6:262. doi:10.3389/fimmu.2015.00262

9. Pangburn MK, Rawal N. Structure and function of complement C5 convertase enzymes. Biochem Soc Trans (2002) 30:1006-10. doi:10.1042/bst030a098c

10. Medof ME, Kinoshita T, Nussenzweig V. Inhibition of complement activation on the surface of cells after incorporation of decay-accelerating factor (DAF) into their membranes. J Exp Med (1984) 160:1558-78. doi:10.1084/ jem.160.5.1558

11. Krych-Goldberg M, Hauhart RE, Subramanian VB, Yurcisin BM, Crimmins DL, Hourcade DE, et al. Decay accelerating activity of complement receptor type 1 (CD35). J Biol Chem (1999) 274:31160-8. doi:10.1074/jbc.274.44.31160

12. Harder MJ, Anliker M, Höchsmann B, Simmet T, Huber-Lang $M$, Schrezenmeier $\mathrm{H}$, et al. Comparative analysis of novel complement-targeted inhibitors, MiniFH, and the natural regulators factor $\mathrm{H}$ and factor $\mathrm{H}$-like 
protein 1 reveal functional determinants of complement regulation. J Immunol (2016) 196:866-76. doi:10.4049/jimmunol.1501919

13. Harris CL, Abbott RJM, Smith RA, Morgan BP, Lea SM. Molecular dissection of interactions between components of the alternative pathway of complement and decay accelerating factor (CD55). J Biol Chem (2005) 280:2569-78. doi:10.1074/jbc.M410179200

14. Okroj M, Holmquist E, King BC, Blom AM. Functional analyses of complement convertases using C3 and C5-depleted sera. PLoS One (2012) 7: e47245. doi:10.1371/journal.pone.0047245

15. Bajic G, Degn SE, Thiel S, Andersen GR. Complement activation, regulation, and molecular basis for complement-related diseases. EMBO J (2015) 34:2735-57. doi:10.15252/embj.201591881

16. Jongerius I, Köhl J, Pandey MK, Ruyken M, van Kessel KPM, van Strijp JAG, et al. Staphylococcal complement evasion by various convertase-blocking molecules. J Exp Med (2007) 204:2461-71. doi:10.1084/jem.20070818

17. Rooijakkers SHM, van Strijp JAG. Bacterial complement evasion. Mol Immunol (2007) 44:23-32. doi:10.1016/j.molimm.2006.06.011

18. Ricklin D, Lambris JD. Complement in immune and inflammatory disorders: therapeutic interventions. J Immunol (2013) 190:3839-47. doi:10.4049/ jimmunol. 1203200

19. Durocher Y, Perret S, Kamen A. High-level and high-throughput recombinant protein production by transient transfection of suspension-growing human 293-EBNA1 cells. Nucleic Acids Res (2002) 30:E9. doi:10.1093/nar/ 30.2.e9

20. Nunn MA, Sharma A, Paesen GC, Adamson S, Lissina O, Willis AC, et al. Complement inhibitor of C5 activation from the soft tick Ornithodoros moubata. J Immunol (2005) 174:2084-91. doi:10.4049/jimmunol.174.4.2084

21. Hammel M, Sfyroera G, Ricklin D, Magotti P, Lambris JD, Geisbrecht BV. A structural basis for complement inhibition by Staphylococcus aureus. Nat Immunol (2007) 8:430-7. doi:10.1038/ni1450

22. Geisbrecht BV, Bouyain S, Pop M. An optimized system for expression and purification of secreted bacterial proteins. Protein Expr Purif (2006) 46: 23-32. doi:10.1016/j.pep.2005.09.003

23. Hammel M, Sfyroera G, Pyrpassopoulos S, Ricklin D, Ramyar KX, Pop M, et al. Characterization of Ehp, a secreted complement inhibitory protein from Staphylococcus aureus. J Biol Chem (2007) 282:30051-61. doi:10.1074/jbc. M704247200

24. Bestebroer J, Aerts PC, Rooijakkers SHM, Pandey MK, Köhl J, Van Strijp JAG, et al. Functional basis for complement evasion by staphylococcal superantigenlike 7. Cell Microbiol (2010) 12:1506-16. doi:10.1111/j.1462-5822.2010. 01486.x

25. Gonzales N. Minimizing immunogenicity of the SDR-grafted humanized antibody CC49 by genetic manipulation of the framework residues. Mol Immunol (2003) 40:337-49. doi:10.1016/S0161-5890(03)00166-4

26. van de Weijer ML, Bassik MC, Luteijn RD, Voorburg CM, Lohuis MAM, Kremmer E, et al. A high-coverage shRNA screen identifies TMEM129 as an E3 ligase involved in ER-associated protein degradation. Nat Commun (2014) 5:3832. doi: $10.1038 /$ ncomms 4832

27. Rawal N, Pangburn MK. C5 convertase of the alternative pathway of complement. J Biol Chem (1998) 273:16828-35. doi:10.1074/jbc.273.27.16828

28. Sarrias MR, Franchini S, Canziani G, Argyropoulos E, Moore WT, Sahu A, et al. Kinetic analysis of the interactions of complement receptor 2 (CR2, CD21) with its ligands C3d, iC3b, and the EBV glycoprotein gp350/220. J Immunol (2001) 167:1490-9. doi:10.4049/jimmunol.167.3.1490

29. Kew RR, Peng T, DiMartino SJ, Madhavan D, Weinman SJ, Cheng D, et al. Undifferentiated U937 cells transfected with chemoattractant receptors: a model system to investigate chemotactic mechanisms and receptor structure/function relationships. JLeukoc Biol (1997) 61:329-37. doi:10.1002/ jlb.61.3.329

30. Veldkamp KE, Heezius HC, Verhoef J, van Strijp JA, van Kessel KP. Modulation of neutrophil chemokine receptors by Staphylococcus aureus supernate. Infect Immun (2000) 68:5908-13. doi:10.1128/IAI.68.10.5908-5913.2000

31. Wiesmann C, Katschke KJ, Yin J, Helmy KY, Steffek M, Fairbrother WJ, et al. Structure of C3b in complex with CRIg gives insights into regulation of complement activation. Nature (2006) 444:217-20. doi:10.1038/ nature 05263

32. Helmy KY, Katschke KJ, Gorgani NN, Kljavin NM, Elliott JM, Diehl L, et al. CRIg: a macrophage complement receptor required for phagocytosis of circulating pathogens. Cell (2006) 124:915-27. doi:10.1016/j.cell.2005.12.039
33. Józsi M. Factor $\mathrm{H}$ family proteins in complement evasion of microorganisms. Front Immunol (2017) 8:571. doi:10.3389/fimmu.2017.00571

34. Kopp A, Hebecker M, Svobodová E, Józsi M. Factor H: a complement regulator in health and disease, and a mediator of cellular interactions. Biomolecules (2012) 2:46-75. doi:10.3390/biom2010046

35. McRae JL, Cowan PJ, Power DA, Mitchelhill KI, Kemp BE, Morgan BP, et al. Human factor H-related protein 5 (FHR-5): a new complement-associated protein. J Biol Chem (2001) 276:6747-54. doi:10.1074/jbc.M007495200

36. Lee LYL, Höök M, Haviland D, Wetsel RA, Yonter EO, Syribeys P, et al. Inhibition of complement activation by a secreted Staphylococcus aureus protein. J Infect Dis (2004) 190:571-9. doi:10.1086/422259

37. Langley R, Wines B, Willoughby N, Basu I, Proft T, Fraser JD. The staphylococcal superantigen-like protein 7 binds IgA and complement $\mathrm{C} 5$ and inhibits IgA-Fc RI binding and serum killing of bacteria. J Immunol (2005) 174:2926-33. doi:10.4049/jimmunol.174.5.2926

38. Rother RP, Rollins SA, Mojcik CF, Brodsky RA, Bell L. Discovery and development of the complement inhibitor eculizumab for the treatment of paroxysmal nocturnal hemoglobinuria. Nat Biotechnol (2007) 25:1256-64. doi:10.1038/nbt1344

39. Qu H, Ricklin D, Bai H, Chen H, Reis ES, Maciejewski M, et al. New analogs of the clinical complement inhibitor compstatin with subnanomolar affinity and enhanced pharmacokinetic properties. Immunobiology (2013) 218: 496-505. doi:10.1016/j.imbio.2012.06.003

40. Gigli I, Fujita T, Nussenzweig V. Modulation of the classical pathway C3 convertase by plasma proteins $\mathrm{C} 4$ binding protein and $\mathrm{C} 3 \mathrm{~b}$ inactivator. Proc Natl Acad Sci U S A (1979) 76:6596-600. doi:10.1073/pnas.76.12.6596

41. Janssen BJC, Halff EF, Lambris JD, Gros P. Structure of compstatin in complex with complement component $\mathrm{C} 3 \mathrm{c}$ reveals a new mechanism of complement inhibition. J Biol Chem (2007) 282:29241-7. doi:10.1074/jbc. M704587200

42. Sahu A, Kay BK, Lambris JD. Inhibition of human complement by a C3-binding peptide isolated from a phage-displayed random peptide library. J Immunol (1996) 157:884-91.

43. Wu J, Wu YQ, Ricklin D, Janssen BJC, Lambris JD, Gros P. Structure of complement fragment C3b-factor $\mathrm{H}$ and implications for host protection by complement regulators. Nat Immunol (2009) 10:728-33. doi:10.1038/ni.1755

44. Kajander T, Lehtinen MJ, Hyvarinen S, Bhattacharjee A, Leung E, Isenman DE, et al. Dual interaction of factor $\mathrm{H}$ with C3d and glycosaminoglycans in hostnonhost discrimination by complement. Proc Natl Acad Sci U S A (2011) 108:2897-902. doi:10.1073/pnas.1017087108

45. McRae JL, Duthy TG, Griggs KM, Ormsby RJ, Cowan PJ, Cromer BA, et al. Human factor H-related protein 5 has cofactor activity, inhibits C3 convertase activity, binds heparin and C-reactive protein, and associates with lipoprotein. J Immunol (2005) 174:6250-6. doi:10.4049/jimmunol.174.10.6250

46. Lee LYL, Liang X, Höök M, Brown EL. Identification and characterization of the C3 binding domain of the Staphylococcus aureus extracellular fibrinogenbinding protein (Efb). J Biol Chem (2004) 279:50710-6. doi:10.1074/jbc. M408570200

47. Laursen NS, Andersen KR, Braren I, Spillner E, Sottrup-Jensen L, Andersen GR. Substrate recognition by complement convertases revealed in the C5-cobra venom factor complex.EMBOJ(2011) 30:606-16. doi:10.1038/emboj.2010.341

48. Laursen NS, Gordon N, Hermans S, Lorenz N, Jackson N, Wines B, et al. Structural basis for inhibition of complement C5 by the SSL7 protein from Staphylococcus aureus. Proc Natl Acad Sci U S A (2010) 107:3681-6. doi:10.1073/pnas.0910565107

49. Jore MM, Johnson S, Sheppard D, Barber NM, Li YI, Nunn MA, et al. Structural basis for therapeutic inhibition of complement C5. Nat Struct Mol Biol (2016) 23:378-86. doi:10.1038/nsmb.3196

50. Fredslund F, Laursen NS, Roversi P, Jenner L, Oliveira CLP, Pedersen JS, et al. Structure of and influence of a tick complement inhibitor on human complement component 5. Nat Immunol (2008) 9:753-60. doi:10.1038/ ni0808-945

51. Kaplan M. Eculizumab (Alexion). Curr Opin Investig Drugs (2002) 3:1017-23.

52. Schatz-Jakobsen JA, Zhang Y, Johnson K, Neill A, Sheridan D, Andersen GR. Structural basis for eculizumab-mediated inhibition of the complement terminal pathway. J Immunol (2016) 197:337-44. doi:10.4049/jimmunol. 1600280

53. Scharfstein J. Human C4-binding protein. I. Isolation and characterization. J Exp Med (1978) 148:207-22. doi:10.1084/jem.148.1.207 
54. Rawal N, Rajagopalan R, Salvi VP. Stringent regulation of complement lectin pathway C3/C5 convertase by C4b-binding protein (C4BP). Mol Immunol (2009) 46:2902-10. doi:10.1016/j.molimm.2009.07.006

55. Rooijakkers SHM, Wu J, Ruyken M, van Domselaar R, Planken KL, Tzekou A, et al. Structural and functional implications of the alternative complement pathway C3 convertase stabilized by a staphylococcal inhibitor. Nat Immunol (2009) 10:721-7. doi:10.1038/ni.1756

56. Pangburn MK. Spontaneous reformation of the intramolecular thioester in complement protein $\mathrm{C} 3$ and low temperature capture of a conformational intermediate capable of reformation. J Biol Chem (1992) 267:8584-90.

57. Ricklin D, Lambris JD. Compstatin: a complement inhibitor on its way to clinical application. Adv Exp Med Biol (2008) 632:273-92. doi:10.1016/j. biotechadv.2011.08.021.Secreted

58. Nilsson PH, Thomas AM, Bergseth G, Gustavsen A, Volokhina EB, van den Heuvel LP, et al. Eculizumab-C5 complexes express a C5a neoepitope in vivo: consequences for interpretation of patient complement analyses. Mol Immunol (2017) 89:111-4. doi:10.1016/j.molimm.2017.05.021

59. Rawal N, Pangburn MK. Formation of high-affinity C5 convertases of the alternative pathway of complement. JImmunol (2001) 166:2635-42. doi:10.4049/jimmunol.166.4.2635

60. Sim RB, Twose TM, Paterson DS, Sim E. The covalent-binding reaction of complement component C3. Biochem J (1981) 193:115-27. doi:10.1042/ bj1930115

61. Mortensen S, Kidmose RT, Petersen SV, Szilágyi Á, Prohászka Z, Andersen GR. Structural basis for the function of complement component C4 within the classical and lectin pathways of complement. J Immunol (2015) 194:5488-96. doi:10.4049/jimmunol.1500087

62. Kinoshita T, Takata Y, Kozono H, Takeda J, Hong KS, Inoue K. C5 convertase of the alternative complement pathway: covalent linkage between two C3b molecules within the trimolecular complex enzyme. J Immunol (1988) 141:3895-901.

63. Kim YU, Carroll MC, Isenman DE, Nonaka M, Pramoonjago P, Takeda J, et al. Covalent binding of $\mathrm{C} 3 \mathrm{~b}$ to $\mathrm{C} 4 \mathrm{~b}$ within the classical complement pathway C5 convertase. J Biol Chem (1992) 267:4171-6.

64. Katschke KJ, Stawicki S, Yin J, Steffek M, Xi H, Sturgeon L, et al. Structural and functional analysis of a C3b-specific antibody that selectively inhibits the alternative pathway of complement. J Biol Chem (2009) 284:10473-9. doi:10.1074/jbc.M809106200

65. Forneris F, Ricklin D, Wu J, Tzekou A, Wallace RS, Lambris JD, et al. Structures of $\mathrm{C} 3 \mathrm{~b}$ in complex with factors $\mathrm{B}$ and $\mathrm{D}$ give insight into complement convertase formation. Science (2010) 330:1816-20. doi:10.1126/science.1195821

66. Janssen BJC, Christodoulidou A, McCarthy A, Lambris JD, Gros P. Structure of $\mathrm{C} 3 \mathrm{~b}$ reveals conformational changes that underlie complement activity. Nature (2006) 444:213-6. doi:10.1038/nature05172

67. Garcia BL, Ramyar KX, Tzekou A, Ricklin D, McWhorter WJ, Lambris JD, et al. Molecular basis for complement recognition and inhibition determined by crystallographic studies of the staphylococcal complement inhibitor (SCIN) bound to C3c and C3b. J Mol Biol (2010) 402:17-29. doi:10.1016/j. jmb.2010.07.029

68. Forneris F, Wu J, Xue X, Ricklin D, Lin Z, Sfyroera G, et al. Regulators of complement activity mediate inhibitory mechanisms through a common C3bbinding mode. EMBO J (2016) 35:1133-49. doi:10.15252/embj.201593673
69. Xue X, Wu J, Ricklin D, Forneris F, Di Crescenzio P, Schmidt CQ, et al. Regulator-dependent mechanisms of $\mathrm{C} 3 \mathrm{~b}$ processing by factor I allow differentiation of immune responses. Nat Struct Mol Biol (2017) 24:643-51. doi: $10.1038 / \mathrm{nsmb} .3427$

70. Nishida N, Walz T, Springer TA. Structural transitions of complement component C3 and its activation products. Proc Natl Acad Sci U S A (2006) 103:19737-42. doi:10.1073/pnas.0609791104

71. Chen H, Ricklin D, Hammel M, Garcia BL, McWhorter WJ, Sfyroera G, et al. Allosteric inhibition of complement function by a staphylococcal immune evasion protein. Proc Natl Acad Sci U S A (2010) 107:17621-6. doi:10.1073/ pnas. 1003750107

72. Alcorlo M, Tortajada A, Rodriguez de Cordoba S, Llorca O. Structural basis for the stabilization of the complement alternative pathway $\mathrm{C} 3$ convertase by properdin. Proc Natl Acad Sci U S A (2013) 110:13504-9. doi:10.1073/ pnas. 1309618110

73. Rodriguez E, Nan R, Li K, Gor J, Perkins SJ. A revised mechanism for the activation of complement C3 to C3b. J Biol Chem (2015) 290:2334-50. doi:10.1074/jbc.M114.605691

74. López-Perrote A, Harrison RES, Subías M, Alcorlo M, Rodríguez de Córdoba S, Morikis D, et al. Ionic tethering contributes to the conformational stability and function of complement C3b. Mol Immunol (2017) 85:137-47. doi:10.1016/j. molimm.2016.12.015

75. Goicoechea de Jorge E, Caesar JJE, Malik TH, Patel M, Colledge M, Johnson S, et al. Dimerization of complement factor $\mathrm{H}$-related proteins modulates complement activation in vivo. Proc Natl Acad Sci U S A (2013) 110:4685-90. doi:10.1073/pnas.1219260110

76. Csincsi ÁI, Szabó Z, Bánlaki Z, Uzonyi B, Cserhalmi M, Kárpáti É, et al. FHR-1 binds to C-reactive protein and enhances rather than inhibits complement activation. J Immunol (2017) 199:292-303. doi:10.4049/jimmunol. 1600483

77. Sfyroera G, Ricklin D, Reis ES, Chen H, Wu EL, Kaznessis YN, et al. Rare loss-of-function mutation in complement component $\mathrm{C} 3$ provides insight into molecular and pathophysiological determinants of complement activity. J Immunol (2015) 194:3305-16. doi:10.4049/jimmunol.1402781

78. Morgan HP, Schmidt CQ, Guariento M, Blaum BS, Gillespie D, Herbert AP, et al. Structural basis for engagement by complement factor $\mathrm{H}$ of $\mathrm{C} 3 \mathrm{~b}$ on a self surface. Nat Struct Mol Biol (2011) 18:463-71. doi:10.1038/nsmb.2018

79. DiScipio RG. The binding of human complement proteins $\mathrm{C} 5$, factor B, beta $1 \mathrm{H}$ and properdin to complement fragment C3b on zymosan. Biochem J (1981) 199:485-96. doi:10.1042/bj1990485

Conflict of Interest Statement: The authors declare that the research was conducted in the absence of any commercial or financial relationships that could be construed as a potential conflict of interest.

Copyright $\odot 2018$ Zwarthoff, Berends, Mol, Ruyken, Aerts, Józsi, de Haas, Rooijakkers and Gorham. This is an open-access article distributed under the terms of the Creative Commons Attribution License (CC BY). The use, distribution or reproduction in other forums is permitted, provided the original author(s) and the copyright owner(s) are credited and that the original publication in this journal is cited, in accordance with accepted academic practice. No use, distribution or reproduction is permitted which does not comply with these terms. 